\title{
Main processes of the Atlantic cold tongue interannual variability
}

\author{
Yann Planton, Aurore Voldoire, Hervé Giordani, Guy Caniaux \\ CNRM-UMR1357, Météo-France/CNRS, CNRM-GAME, Toulouse, France \\ e-mail: yann.planton@gmail.com
}

\begin{abstract}
The interannual variability of the Atlantic cold tongue (ACT) is studied by means of a mixedlayer heat budget analysis. A method to classify extreme cold and warm ACT events is proposed and applied to ten various analysis and reanalysis products. This classification allows five cold and five warm ACT events to be selected over the period 1982-2007. Cold (warm) ACT events are defined by the presence of negative (positive) sea surface temperature (SST) anomalies at the center of the equatorial Atlantic in late boreal spring, preceded by negative (positive) zonal wind stress anomalies in the western equatorial Atlantic. An ocean general circulation model capable of reconstructing the interannual variability of the ACT correctly is used to demonstrate that cold ACT events develop rapidly from May to June mainly due to intense cooling by vertical mixing and horizontal advection. The simulated cooling at the center of the basin is the result of the combined effects of non-local and local processes. The non-local process is an upwelling associated with an eastward-propagating Kelvin wave, which makes the mixed-layer more shallow and preconditions the upper layers to be cooled by an intense heat loss at the base of the mixed-layer, which is amplified by a stronger local injection of energy from the atmosphere. The early cooling by vertical mixing in March is also shown to be a good predictor of June cooling. In July, horizontal advection starts to warm the mixed-layer abnormally and damps SST anomalies. The advection anomalies, which result from changes in the horizontal temperature gradient, are associated in some cases with the propagation of Rossby waves along the equator. During warm ACT events, processes are reversed, generating positive SST anomalies: a downwelling Kelvin wave triggers stratification anomalies and mixed-layer depth anomalies, amplified by a weaker injection of energy from the atmosphere in May-June. In July, warm ACT events are abnormally cooled due to negative horizontal advection anomalies resulting from processes similar to those that occur during cold ACT events. This additional cooling process extends the period of cooling of the ACT, reducing SST anomalies.
\end{abstract}

Keywords: Atlantic cold tongue, Equatorial Atlantic, Interannual variability, Mixed-layer heat budget, Oceanic mixed-layer processes, Vertical mixing

\section{Introduction}

The Eastern Equatorial Atlantic (EEA) is strongly linked to the West African monsoon (Gu and Adler 2004; Okumura and Xie 2004; Caniaux et al. 2011; Nguyen et al. 2011). This is due to the EEA's strong seasonal cycle (Wauthy 1983) and particularly that of the Atlantic cold tongue (ACT), which is characterized by an intense cooling from May to July, when sea surface temperatures (SSTs) decrease by $5^{\circ} \mathrm{C}$ to $7^{\circ} \mathrm{C}$ (Merle et al. 1979; Weingartner and Weisberg 1991a). Indeed, the onset of the ACT is well correlated with the intensification of the easterly trade winds (Hastenrath and Lamb 1978) and the northward shift of the Intertropical Convergence Zone (Picaut 1983; Colin 1989; Waliser and Gautier 1993). In addition, the West African monsoon onset follows the ACT onset by a few weeks (Caniaux et al. 2011).

The cooling of the ACT was recently studied through both observations (Foltz et al. 2003; Wade et al. 2011b; Hummels et al. 2013, 2014; Schlundt et al. 2014) and model simulations (Peter 
et al. 2006; Jouanno et al. 2011a, 2011b; Giordani et al. 2013). In all of these works, the subsurface processes were shown to be the main source of cooling. More precisely, studies by Jouanno et al. (2011a, 2011b) and Giordani et al. (2013) demonstrate that vertical mixing at the base of the mixedlayer generates intense heat loss as high as $100 \mathrm{~W} / \mathrm{m}^{2}$ and is the most important contributor to the cooling of the ACT. Such intensities were confirmed by microstructure measurements at $10^{\circ} \mathrm{W}$ at the equator by Hummels et al. $(2013,2014)$.

In both the Atlantic and the Pacific, the seasonal cycle of vertical mixing is controlled by the production of turbulent kinetic energy (TKE) modulated primarily by the vertical shear between the South Equatorial Current (SEC) and the Equatorial Undercurrent (EUC) (e.g. Gregg et al. 1985; Moum and Caldwell 1985; Jouanno et al. 2013). This shear reaches a peak during the boreal summer, with the acceleration of the SEC. At the intraseasonal scale, equatorial waves (Kelvin waves, Rossby-gravity waves, Rossby waves - the last two could also be referred as Tropical Instability Waves: TIW) also modulate the production of TKE along the equator (Lien et al. 2008; Jouanno et al. 2013; Hummels et al. 2013).

Recent studies indicate that the entrainment (including vertical advection) is weak on average along the equator (Jouanno et al. 2011a, 2011b; Wade et al. 2011b; Giordani et al. 2013). However, upwelling estimates inferred from helium isotope disequilibrium suggest that vertical advection could be significant, but only at small temporal and space scales (Rhein et al. 2010).

Philander and Pacanowski (1981) proposed that the ACT could be formed by advection of cold water from the southern coastal upwelling areas by equatorial currents. Schlundt et al. (2014) established that horizontal advection cools the ACT, but clearly to a lesser degree than vertical mixing. Other studies agree that the contribution of horizontal advection to the development of the cold tongue is weak (Foltz et al. 2003; Jouanno et al. 2011a, 2011b; Wade et al. 2011b; Giordani et al. 2013; Hummels et al. 2013, 2014).

Caniaux et al. (2011) define a variety of indices to characterize the interannual variability of the ACT in terms of surface area, maximum surface extension, mean temperature, dates of formation and dissipation, and duration. The mean surface area ranges from 0.65 to $1.49 \times 10^{6} \mathrm{~km}^{2}$ (reached in 1984 and 1992, respectively); the earliest date of formation is May 192005 and the latest July 4 1995. These two indicators are anti-correlated (-0.47), meaning that the ACT cooling is generally more widespread when it starts earlier. However, the correlation is not very high, indicating that multiple sources of ACT variability exist.

The role of the wind in the Western Equatorial Atlantic (WEA) in controlling the ACT has been underlined in several studies (Servain et al. 1982; Ding et al. 2010; Burls et al. 2012; Richter et al. 2013), with wind anomalies in the WEA preceding SST anomalies in the EEA by 1-2 months (Servain et al. 1982; Keenlyside and Latif 2007; Burls et al. 2012). As in the Pacific, the Bjerknes feedback is one of the mechanisms that control the variability of the ACT (Keenlyside and Latif 2007; Lübbeke and McPhaden 2013). However, it is of less importance here than in the Pacific, where it is largely responsible for the El Niño Southern Oscillation. Keenlyside and Latif (2007) conclude that other mechanisms must also be at play in the Atlantic.

Most SST anomalies in the ACT are associated with wind anomalies of the same sign (i.e. cold SST anomalies associated with increased winds, and conversely) in the WEA (Servain et al. 1982; Ding et al. 2010; Burls et al. 2012; Richter et al. 2013), but some ACT events do not follow these dynamics (Richter et al. 2013; Brandt et al. 2014). The former type of events are usually called "canonical events," while the latter are called "non-canonical events."

To understand the main mechanisms of interannual variability, studies are essentially focused on canonical ACT events. Several studies have suggested that wind anomalies along the equator could be forced by remote perturbations. Recently, Lübbecke et al. (2014) established a relationship between the sea level pressure of the South Atlantic Anticyclone (SAA, the St. Helena anticyclone) and SST anomalies in the EEA. They found that an anomalously strong (weak) SAA in February March leads to an earlier (later) onset of the ACT and to an anomalously cold (warm) ACT. However, the mechanisms linking SAA and SST anomalies are still unclear. On the other hand, 
Richter et al. (2014) showed that the boreal spring wind variability in the equatorial Atlantic is mainly controlled by entrainment of free tropospheric properties into the planetary boundary layer (PBL) and contributions of the free troposphere to the surface pressure gradient, rather than surface pressure gradients associated with SST gradients. Most of these studies (Richter et al. 2013, 2014) point to the importance of the wind, but the associated ocean mechanisms are less well described.

From the ocean perspective, Burls et al. (2012) also emphasized the role of the wind in controlling the energetics of the upper ocean and could not find a clear signal of ocean preconditioning. Brandt et al. (2014) investigated the impact of the EUC on EEA and ACT variability. They established that intense (weak) boreal spring winds could increase (weaken) the boreal summer EUC transport and generate colder (warmer) SST anomalies. Using Argo floats data for the period from 2005 to 2007 of the AMMA/EGEE experiment (Redelsperger et al. 2006), Wade et al. (2011b) observed significant differences in the cooling of the ACT during this threeyear period and inferred that the intensity and duration of intense vertical mixing could account for this variability.

The aim of the present study is to explore the ocean processes associated with the so-called canonical years. To that end, a systematic selection of the coldest and warmest ACT events over the period 1982-2007 was made using a classification (described in Section 2) similar to that proposed by Richter et al. (2013). By applying the classification to a large variety of reanalysis products, the final selection (a group of five warm and five cold ACT events, common to all the reanalysis products) allowed significantly contrasted ACT events to be retained. A forced global ocean general circulation model was used to investigate the oceanic processes at the origin of each group of events. The model, able to reproduce the interannual variability of the EEA and particularly the extreme ACT events, allows the computation of a mixed-layer heat budget for identifying the processes that control the interannual variability of the ACT (Sections 3 and 4).

\begin{tabular}{|c|c|c|c|c|c|c|c|}
\hline \multirow{2}{*}{ Name } & \multirow{2}{*}{ Nickname } & \multirow{2}{*}{ Type } & \multirow{2}{*}{ Resolution } & \multirow{2}{*}{ Reference } & \multicolumn{3}{|c|}{$\begin{array}{l}\text { Variables available for the } \\
\text { classification }\end{array}$} \\
\hline & & & & & SST & $\begin{array}{c}\text { Zonal wind } \\
\text { stress }\end{array}$ & Period \\
\hline $\begin{array}{l}\text { ARMOR 3D } \\
\text { L4 }\end{array}$ & ARMOR & $\begin{array}{l}\text { Ocean } \\
\text { analysis }\end{array}$ & $\begin{array}{c}1 / 3^{\circ} \\
0-1500 \mathrm{~m} \\
24 \text { levels } \\
\end{array}$ & $\begin{array}{l}\text { Guinehut et } \\
\text { al. (2012) }\end{array}$ & $\mathrm{X}$ & & $1990-2007$ \\
\hline CORA & CORA & $\begin{array}{c}\text { Ocean } \\
\text { analysis }\end{array}$ & $\begin{array}{c}1^{\circ} \\
59 \text { levels }^{\circ}\end{array}$ & $\begin{array}{l}\text { Cabanes et } \\
\text { al. }(2013)\end{array}$ & $X$ & & $1993-2007$ \\
\hline ERA-I & ERA-I & $\begin{array}{l}\text { Atmospheric } \\
\text { reanalysis }\end{array}$ & $\begin{array}{c}\text { T255 } \\
(\sim 80 \mathrm{~km}) \\
60 \text { levels }\end{array}$ & $\begin{array}{l}\text { Dee et al. } \\
(2011)\end{array}$ & $X$ & $X$ & $1982-2007$ \\
\hline GODAS & GODAS & $\begin{array}{l}\text { Ocean } \\
\text { reanalysis }\end{array}$ & $\begin{array}{c}1^{\circ} \\
40 \text { levels }\end{array}$ & $\begin{array}{l}\text { Saha et al. } \\
(2010)\end{array}$ & $X$ & $X$ & $1982-2007$ \\
\hline ICOADS & ICOAD & $\begin{array}{c}\text { Atmospheric } \\
\text { surface } \\
\text { analysis }\end{array}$ & $\begin{array}{c}2^{\circ} \\
\text { Surface }\end{array}$ & $\begin{array}{l}\text { Woodruff et } \\
\text { al. }(2011)\end{array}$ & $\mathrm{X}$ & & $1982-2007$ \\
\hline $\begin{array}{c}\text { NCEP } \\
\text { Reanalysis } 2\end{array}$ & NCEP2 & $\begin{array}{l}\text { Atmospheric } \\
\text { reanalysis }\end{array}$ & $\begin{array}{c}2,5^{\circ} \\
28 \text { levels }\end{array}$ & $\begin{array}{c}\text { Kanamitsu et } \\
\text { al. (2002) }\end{array}$ & $X$ & $X$ & $1982-2007$ \\
\hline $\begin{array}{l}\text { NEMOVAR } \\
1 \text { COMBINE }\end{array}$ & COMBI & $\begin{array}{c}\text { Ocean } \\
\text { reanalysis }\end{array}$ & $\begin{array}{c}1^{\circ} \\
42 \text { levels }\end{array}$ & $\begin{array}{l}\text { Balmaseda et } \\
\text { al. (2010) }\end{array}$ & $X$ & $X$ & $1982-2007$ \\
\hline $\begin{array}{l}\text { Reynolds et } \\
\text { al.'s (2007) } \\
\text { SSTs } \\
\end{array}$ & REYNO & $\begin{array}{l}\text { Gridded } \\
\text { surface } \\
\text { ocean data } \\
\end{array}$ & $\begin{array}{l}1 / 4^{\circ} \\
\text { Surface }\end{array}$ & $\begin{array}{l}\text { Reynolds et } \\
\text { al. (2007) }\end{array}$ & $X$ & & $1982-2007$ \\
\hline ORAS4 & ORAS4 & $\begin{array}{c}\text { Ocean } \\
\text { reanalysis }\end{array}$ & $\begin{array}{c}1^{\circ} \\
42 \text { levels }^{\circ}\end{array}$ & $\begin{array}{l}\text { Balmaseda et } \\
\text { al. (2013) }\end{array}$ & $\mathrm{X}$ & $\mathrm{X}$ & $1982-2007$ \\
\hline TropFlux & Tr_Fl & $\begin{array}{c}\text { Atmospheric } \\
\text { surface } \\
\text { analysis }\end{array}$ & $\begin{array}{c}1^{\circ} \\
\text { Surface }\end{array}$ & $\begin{array}{c}\text { Praveen } \\
\text { Kumar et al. } \\
(2012)\end{array}$ & $\mathrm{X}$ & $X$ & $1982-2007$ \\
\hline
\end{tabular}

Table 1. Datasets used for our classification. 


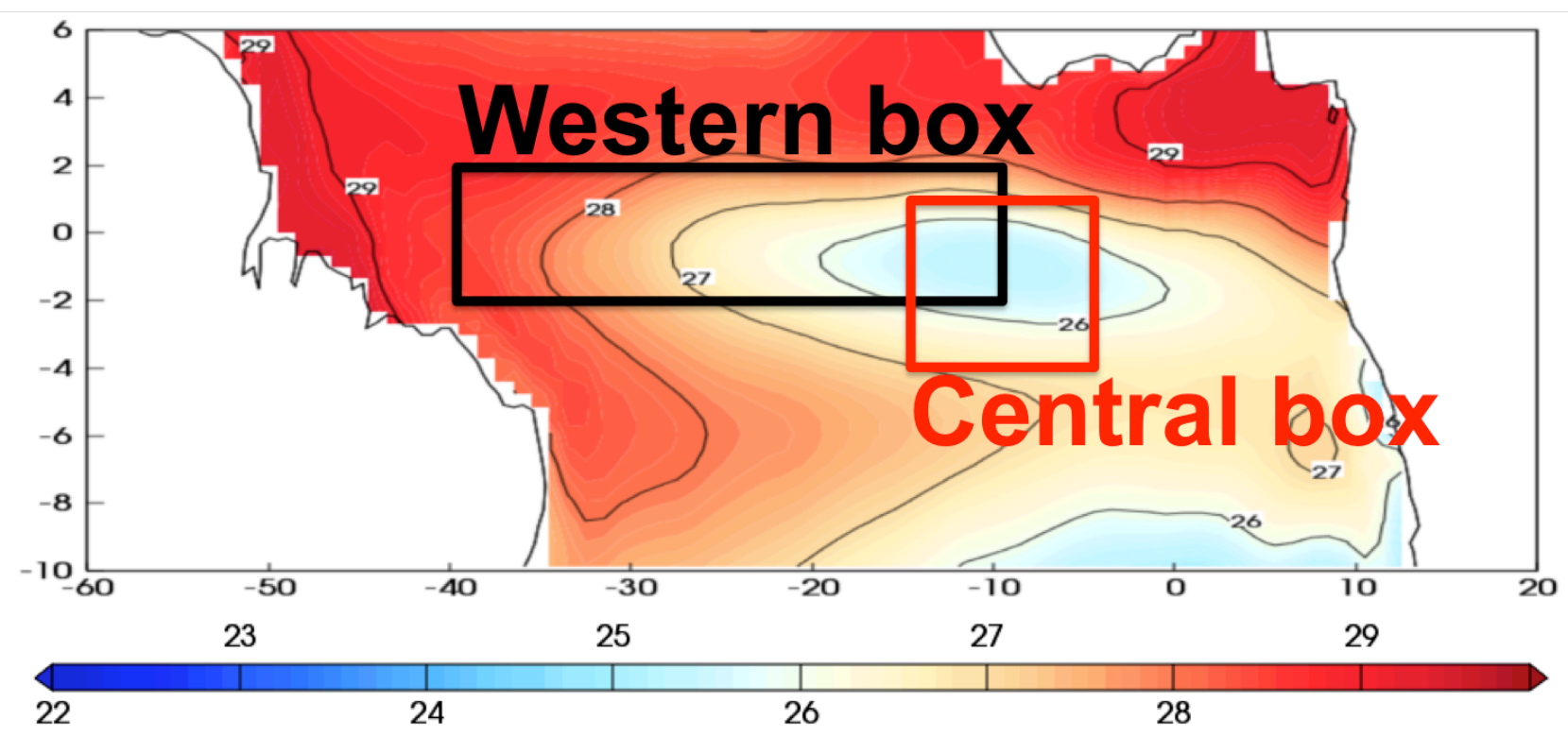

Figure 1. May-July averaged (1982-2007) simulated SST $\left({ }^{\circ} \mathrm{C}\right)$ and spatial delimitations of the boxes used in our classification of cold and warm ACT events (see text).

\section{Method}

\subsection{Classification of ACT events}

This classification was created to select years with strong SST anomalies (the mean annual cycle based on the period 1982-2007, unless otherwise stated, is subtracted to obtain monthly anomalies) in observationally derived and reanalysis datasets. The analysis is focused on the period 1982-2007 in order to maximize the number of datasets available and to match the time period span with the model simulation. Eight products, listed in Table 1, were used for the entire period (19822007), along with two other products covering a shorter time period (CORA for 1990-2007 and ARMOR for 1993-2007). The use of different products ensures the robustness of our selection of the ACT events.

The classification of cold and warm ACT events is derived from the classification proposed by Richter et al. (2013) and is based on the following new criteria, adapted to our region and period of interest:

- SST anomalies (relative to the mean annual cycle) in a central box $\left[15^{\circ} \mathrm{W}-6^{\circ} \mathrm{W}, 4^{\circ} \mathrm{S}-\right.$ $1^{\circ} \mathrm{N}$ ] greater than 0.5 standard deviation (std) during May-July

- Zonal wind stress anomalies (relative to the mean annual cycle) over a western box $\left[40^{\circ} \mathrm{W}-10^{\circ} \mathrm{W}, 2^{\circ} \mathrm{S}-2^{\circ} \mathrm{N}\right]$ greater than 0.1 std during March-May

- SST and zonal wind stress anomalies of the same sign.

Note that removing the linear trend from the SST time series in each model does not change the selected years. The two boxes used for this classification are represented in Figure 1. The central box is centered on $10^{\circ} \mathrm{W}$, where minimum SSTs occur in boreal summer and the ACT starts cooling (Mazeika 1968; Caniaux et al. 2011). Our classification is based on both SST and wind stress, as the seasonal SST variability in the EEA is dominated by remote wind forcing in the WEA with a delay of one or two months (Servain et al. 1982; Keenlyside and Latif 2007). Basically, a warm (cold) ACT event is defined by a SST anomaly at the center of the basin (central box) in late spring preceded by a wind stress anomaly of the same sign in the WEA (western box). The months considered in the classification correspond to the periods when the monthly standard deviations of all datasets reach, on average, a maximum (April-May for stress wind anomalies and June for SST anomalies). 
The selected years are listed in Table 2 . We obtain 5 cold and 5 warm years. The warm years include all years selected by Richter et al. (2013) during the period 1982-2007. Two additional warm ACT events were selected (years 1995 and 1999), as our zonal wind threshold is weaker. However, even though the wind anomaly is weak, these years are selected by all datasets, confirming that these events clearly differ from the normal years. Most of the selected years are also in common with those of Burls et al. (2012); the main difference is our non-selection of years 1987, 1994 and 1998. However, Burls et al. (2012) did not distinguish between canonical and noncanonical ACT events, and these events can be considered as non-canonical (i.e. wind stress anomalies do not have the same sign as SST anomalies). Years 1984 and 1986 are not selected by our classification because the SST anomalies do not exceed 0.5 std in several datasets.

According to the indices established by Caniaux et al. (2011) to characterize the interannual variability of the ACT, the ACT appears earlier (later) during the selected cold (warm) years, and the mean and maximum surface areas of the ACT are generally larger (smaller) (see Table 3). However, each case has its own specificities. For instance, in 2004, the ACT does not start particularly early, and the ACT has not a larger surface area than usual. Among the warm years, 1991 the ACT has one of the largest surface areas of the entire period 1982-2007. On the other hand, the ACT of 1999 starts very close to the mean date, but has one of the smallest surface areas.

\begin{tabular}{|l|l|}
\hline Cold ACT events & Warm ACT events \\
\hline 1983 & 1988 \\
1992 & 1991 \\
1997 & 1995 \\
2004 & 1996 \\
2005 & 1999 \\
\hline
\end{tabular}

Table 2. Selected warm and cold ACT events.

\begin{tabular}{|l|c|c|c|c|}
\cline { 2 - 5 } \multicolumn{1}{c|}{} & Cold & Warm & Mean & Std \\
\hline Mean surface $\left(10^{6} \mathrm{~km}^{2}\right)$ & 1.16 & 0.93 & 0.99 & 0.22 \\
\hline Max surface $\left(10^{6} \mathrm{~km}^{2}\right)$ & 2.89 & 2.34 & 2.56 & 0.50 \\
\hline Date of max surface & $11^{\text {th }}$ of August & $20^{\text {th }}$ of August & $14^{\text {th }}$ of August & 14 days \\
\hline Temperature index $\left({ }^{\circ} \mathrm{C}\right)$ & 0.72 & 0.58 & 0.61 & 0.12 \\
\hline Date of formation & $\mathbf{2 6}^{\text {th }}$ of May & $\mathbf{2 5}^{\text {th }}$ of June & $11^{\text {th }}$ of June & 12 days \\
\hline Date of end & $30^{\text {th }}$ of October & $13^{\text {th }}$ of November & $31^{\text {th }}$ of October & 25 days \\
\hline Duration (days) & 160 & 140 & 149 & 28 \\
\hline
\end{tabular}

Table 3. Statistics of the ACT, based on Caniaux et al. (2011). Cold (warm) values are the mean of the 5 cold (warm) ACT events selected in Table 2. Mean is the averaged value of all ACT during the period 1982-2007. Std is the standard deviation for the period 1982-2007. Values outside one standard deviation are in bold.

\subsection{Model and simulation}

The simulation uses a global configuration of the Nucleus for European Modeling of the Ocean (NEMO version 3.2) (Madec 2008) with a $1^{\circ}$ horizontal resolution and 42 vertical levels. Note that the latitudinal resolution increases to $1 / 3^{\circ}$ in the equatorial region, allowing the equatorial dynamics to be represented. The vertical grid ranges from $10 \mathrm{~m}$ at the surface to $300 \mathrm{~m}$ at $5350 \mathrm{~m}$ depth, with 10 levels in the upper $100 \mathrm{~m}$. The vertical eddy diffusivity and viscosity coefficients are computed using a TKE closure scheme (Blanke and Delecluse 1993). The model is forced by the COREv2 interannually varying forcing (Large and Yeager 2009) representing the period 1948 to 2007. This forcing was created for Coordinated Ocean-sea ice Reference Experiments (CORE) (Griffies et al. 2012), and is composed of 6 hourly fields for the wind, air temperature and humidity, daily fields for shortwave and longwave radiation, and monthly fields for liquid and solid precipitation. A monthly runoff climatology based on Dai and Trenberth (2002) is used. The model is integrated over six cycles of the 60 years of the forcing to ensure that the system has reached an equilibrium. Only the last cycle is used here (Danabasoglu et al. 2014 indicate that the model 
reaches an equilibrium after three cycles). The COREv2 interannually varying forcing has already been used for a similar global configuration of the NEMO model, and showed good results in the North Atlantic (Danabasoglu et al. 2014). Monthly averages covering the period 1982-2007 are used in this study.

Oceanic biology has a strong influence on the top layers $(0-30 \mathrm{~m})$ of the ocean in the tropics (Lengaigne et al. 2007). In our simulation, the penetration of solar irradiance in the water column depends on the physical properties of seawater:

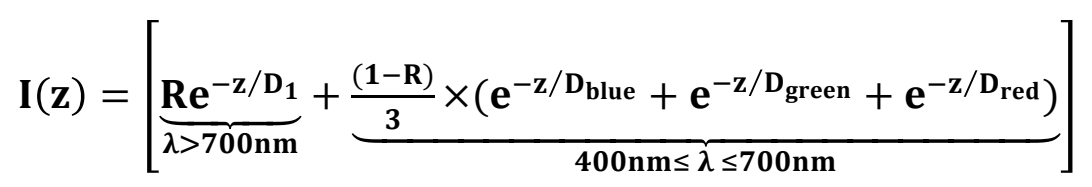

The light partitioning $\mathrm{R}$ and the light attenuation coefficient $\mathrm{D}_{1}$ are set according to Wade et al. (2011a), based on equatorial Atlantic water type. The light attenuation coefficients $D_{\text {blue, }}, D_{\text {green }}$ and $\mathrm{D}_{\text {red }}$ depend on the chlorophyll concentration given by a monthly SeaWIFS chlorophyll climatology (Carr et al. 2006). These chlorophyll-dependent coefficients are fitted on the coefficients computed from the full spectral model of Morel (1988) (modified by Morel and Maritorena 2001). For more information on the method, see Lengaigne et al. (2007). This parameterization impacts the simulation because it enhances solar radiation absorbed within the first ocean layers. It implies a small SST increase (by $1 \%$ on average) but reduces the mean temperature of the first 300 meters (by $3 \%$ on average). Consequently, it sharpens the thermocline, slightly improving the vertical temperature gradient in the first ocean levels. Another effect of this parameterization is to reduce the mixed-layer depth (MLD) by $13 \%$ on average; however in terms of variability in the central box, its standard deviation is similar to that of ocean reanalysis products and its anomalies are well-correlated with those computed with ORAS-4 (0.7).
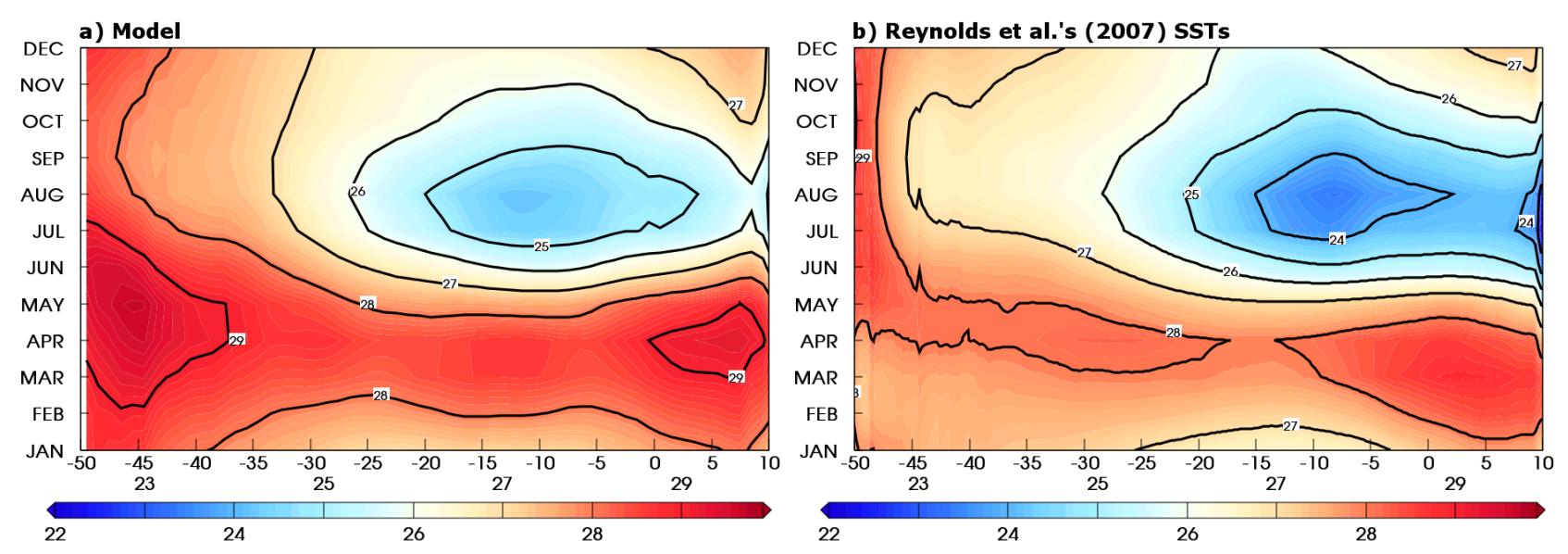

Figure 2. Time versus longitude Hovmöller diagrams (latitude averaged over $4^{\circ} \mathrm{S}-1^{\circ} \mathrm{N}$ ) extending from $50^{\circ} \mathrm{W}$ to $10^{\circ} \mathrm{E}$ of the mean annual cycle (average 1982-2007) a) simulated SST and b) Reynolds et al.'s (2007) SSTs in ${ }^{\circ} \mathrm{C}$ (isoline every $1^{\circ} \mathrm{C}$ ).

\subsection{Evaluation}

The aim of our study is to better understand the mechanisms at work in producing temperature anomalies during contrasted warm and cold ACT events. It is therefore important that the model reproduce the mean seasonal cycle of the Equatorial Atlantic and the interannual variability of the upper ocean realistically. While we performed an extensive evaluation of the model in this region, here we focus on near-surface temperatures and MLDs. In particular, the upper ocean circulation is realistically simulated, although currents are less intense than observed. The classification has been applied to the model data and observed cold and warm events are also detected in the model. 


\subsubsection{Sea surface temperatures}

In the following, we use Reynolds et al.'s (2007) SSTs as a reference to evaluate our model. The mean annual cycle (1982-2007) of the simulated SSTs is compared with the reference SSTs in a time versus longitude Hovmöller diagram averaged over an equatorial band $4^{\circ} \mathrm{S}-1^{\circ} \mathrm{N}$ (Figure 2). Both model and reference SSTs exhibit a large annual cycle, with warmer SSTs in March-April from $50^{\circ} \mathrm{W}$ to $10^{\circ} \mathrm{E}$, and a severe cooling from May to August, with minimum SSTs reached at $10^{\circ} \mathrm{W}$ in August. Both the timing of maximum cooling and the location of the SST minimum are well reproduced by the model. From August to December, the ocean warms at nearly the same rate in the simulation and in the observations. However, along the equator the model has a warm bias independent of the season. This bias is weaker in boreal spring $\left(0.5^{\circ} \mathrm{C}\right)$ than in boreal summer (more than $1^{\circ} \mathrm{C}$ ); this affects the cooling trend at $10^{\circ} \mathrm{W}$, which is of $0.7^{\circ} \mathrm{C} / \mathrm{month}$ in the simulation, compared to $0.9^{\circ} \mathrm{C} /$ month in the reference SSTs.

The simulation reproduces the interannual variability of the reference SSTs quite well and simulates warm and cold ACT events with realistic timing, whereas the amplitude is slightly overestimated (Figure 3a).

With the chlorophyll climatology, the highest concentration of chlorophyll is phase locked to the mean seasonal cooling of the ACT. During cold (warm) ACT events the chlorophyll does not bloom earlier (later) and therefore the amount of solar radiation absorbed within the mixed-layer during the ACT formation may not be high (low) enough. Consequently, SST anomalies are not sufficiently reduced by this phenomenon. We would expect the use of an interannual chlorophyll dataset or a biogeochemical model to reduce the overestimation of some the SST anomalies.

The Taylor diagram (Taylor 2001) provides an additional statistical summary of each dataset's ability to reproduce the interannual variability of the reference SSTs (Figure 3b). The simulation reproduces the interannual variability of the SST quite well in terms of correlation (0.7), normalized standard deviation $\left(1.3^{\circ} \mathrm{C}\right)$ and root mean square $(\mathrm{rms})$ difference $\left(0.5^{\circ} \mathrm{C}\right)$ in comparison to the reference series (Figure $3 \mathrm{~b}$ ). The various observationally derived and reanalysis datasets provide better statistics (correlations greater than 0.8 , normalized standard deviation between 0.7 and $1.1^{\circ} \mathrm{C}$, rms differences greater than $0.35^{\circ} \mathrm{C}$ ), but it is important to keep in mind that the reanalyses assimilate SST fields, whereas our simulation has no SST restoring. Moreover, one dataset was added in Figure 3b: the EN4 v1.7 (Good et al. 2013), not used in our classification, which gives statistics similar to those of our model. This suggests that some observationally derived datasets do not lead to a better reproduction of the interannual variability of the SST than our model.

Even though they are overestimated, the model SST anomalies are realistic enough to allow the analysis of the mixed-layer heat budget.

\subsubsection{Mixed-layer depths}

The MLD is determined by a threshold method; i.e., with a density change of $0.03 \mathrm{~kg} / \mathrm{m}^{3}$ from the density value at $10 \mathrm{~m}$ depth $(\Delta \rho=\rho(z=10 \mathrm{~m})+0.03)$ (de Boyer Montégut et al. 2004). In the model, the density is computed from the potential temperature and salinity using Jackett and McDougall's (1995) formulation.

The mean annual cycle (average 1982-2007) of the simulated MLDs is compared with de Boyer Montégut et al.'s (2004) MLD climatology in a time-versus-longitude Hovmöller diagram in an equatorial band between $4^{\circ} \mathrm{S}$ and $1^{\circ} \mathrm{N}$ (Figure 4). Along the equator, both the reference climatology and the model exhibit MLDs with zonal slopes deeper in the west than in the east throughout the year. East of $0^{\circ} \mathrm{E}$, MLDs remain constant all year, at around $15 \mathrm{~m}$ in both the model and the climatology. From $45^{\circ} \mathrm{W}$ to $30^{\circ} \mathrm{W}$, they deepen from a minimum of $30 \mathrm{~m}$ in January to a maximum of $50 \mathrm{~m}$ from July to December: a seasonal cycle which is reproduced quite well by the model. Between $15^{\circ} \mathrm{W}$ and $0^{\circ} \mathrm{E}$, model MLDs are at their minimum from January to September, with values less than $20 \mathrm{~m}$, and deepen slightly from October to November (20 to $30 \mathrm{~m}$ ), as in the reference climatology. However, the simulated MLDs are $10 \%$ too deep west of $30^{\circ} \mathrm{W}, 18 \%$ too shallow between $30^{\circ} \mathrm{W}$ and $0^{\circ} \mathrm{E}$, and $9 \%$ too deep east of $0^{\circ} \mathrm{E}$ compared with de Boyer Montégut et al.’s (2004) MLD climatology. 
a) SST anomalies in the central box

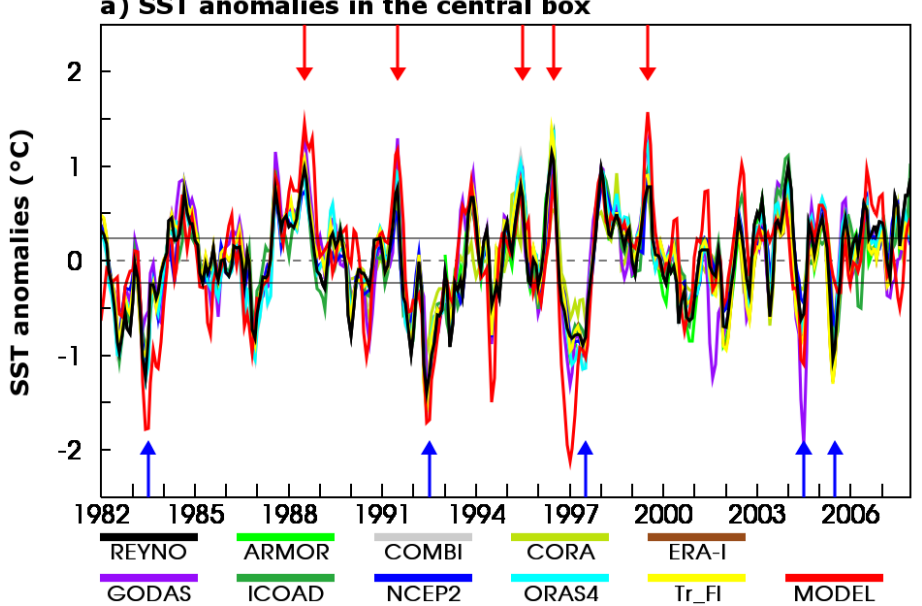

b) Taylor diagram

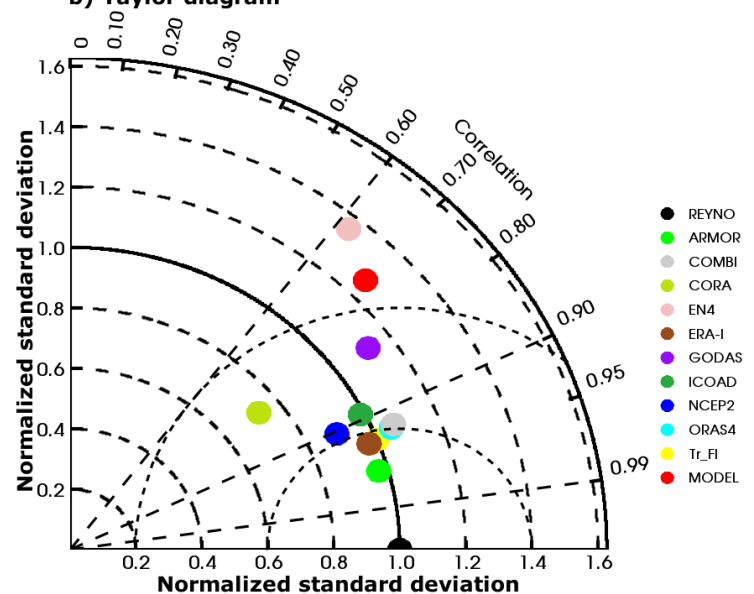

Figure 3. a) Time series of SST anomalies (relative to the mean annual cycle) in ${ }^{\circ} \mathrm{C}$ computed in the central box $\left[15^{\circ} \mathrm{W}-6^{\circ} \mathrm{W}, 4^{\circ} \mathrm{S}-1^{\circ} \mathrm{N}\right]$ from the ten analyses or reanalyses listed in Table 1 and for the model NEMO used in this study (in red). Blue and red arrows indicate the selected years of cold and warm ACT events respectively. b) Taylor's (2001) diagram applied to the 10 analyses and reanalyses listed in Table 1, to the EN4 analysis and to our model results, by using Reynolds et al.'s (2007) SSTs as reference. Black solid and long dashed circles centered on the origin refer to the normalized standard deviation, long dashed lines correspond to the correlation with reference SSTs, and small dashed circles centered on the reference dataset (black dot) refer to the root mean square difference with reference SSTs.
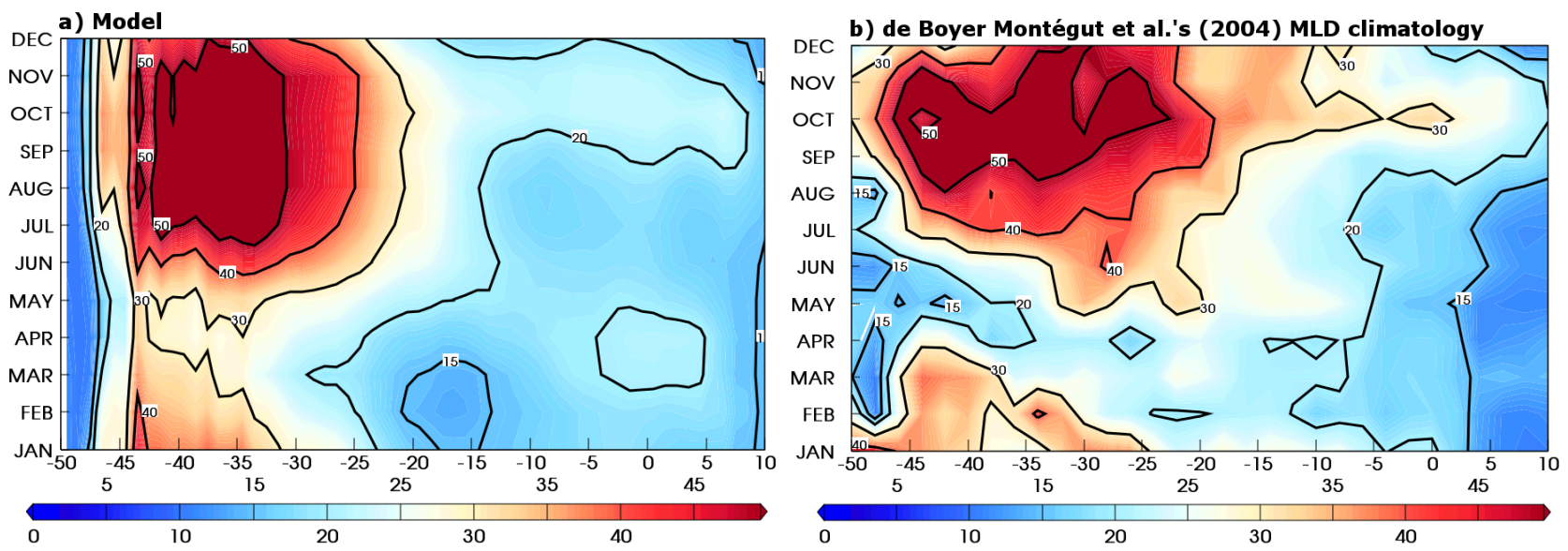

Figure 4. Same as Figure 2 for a) the simulated MLDs and b) de Boyer Montégut et al.'s (2004) MLDs climatology in $\mathrm{m}$ (isoline at $15 \mathrm{~m}$ and $20 \mathrm{~m}$ then every $10 \mathrm{~m}$ ).

\subsection{Mixed-layer heat budget}

The mixed-layer heat budget was estimated online in the model simulation and can be written as follows:

$$
\left\{\begin{array}{c}
\underbrace{\partial_{\mathbf{t}}\langle\mathbf{T}\rangle}_{\text {temperature tendency }}=\underbrace{\frac{1}{\rho_{0} \mathbf{C}_{\mathbf{p}} \mathbf{h}}\left(\mathbf{F}_{\text {sol }}[\mathbf{I}(\mathbf{0})-\mathbf{I}(-\mathbf{h})]+\mathbf{F}_{\mathbf{n s o l}}\right)}_{\text {air-sea heat flux }} \underbrace{-\left\langle\mathbf{U}_{\mathbf{h}} \cdot \nabla \mathbf{T}\right\rangle}_{\text {horizontal heat advection }} \\
\underbrace{-\frac{1}{\mathbf{h}} \mathbf{K}_{\mathbf{z}} \mathbf{\partial}_{\mathbf{z}} \mathbf{T}(-\mathbf{h})}_{\text {vertical mixing }} \underbrace{+\left\langle\mathbf{K}_{\mathbf{h}} \nabla^{2} \mathbf{T}\right\rangle}_{\text {horizontal heat diffusion }} \underbrace{-\frac{1}{\mathbf{h}}[\langle\mathbf{T}\rangle-\mathbf{T}(-\mathbf{h})] \mathbf{W}_{\mathbf{e}}}_{\text {entrainment }}
\end{array}\right.
$$

where

with

$$
\mathbf{w}_{\mathrm{e}}=\partial_{\mathrm{t}} \mathbf{h}+\mathbf{U}_{\mathbf{h}} \cdot \nabla \mathbf{h}+\mathbf{w}(-\mathbf{h})
$$

$$
\langle X\rangle=\frac{1}{h} \int_{-h}^{0} X d z
$$


Here, $T$ is the potential temperature, $\rho_{0}$ the surface-referenced density $\left(\rho_{0}=1035 \mathrm{~kg} / \mathrm{m}^{3}\right), C_{p}$ the heat capacity $\left(\mathrm{C}_{\mathrm{p}}=4178.4 \mathrm{~J} /{ }^{\circ} \mathrm{C}\right), \mathrm{h}$ the $\mathrm{MLD}, \mathrm{F}_{\mathrm{sol}}$ the net shortwave radiation, $\mathrm{I}(\mathrm{z})$ the penetration of solar irradiance at depth $\mathrm{z}, \mathrm{F}_{\mathrm{nsol}}$ the non-solar surface heat flux (sum of the net longwave radiation, the sensible and latent heat fluxes), $\mathrm{U}_{\mathrm{h}}$ the horizontal current, $\mathrm{K}_{\mathrm{z}}$ the vertical turbulent diffusion coefficient (depending on the production of TKE), $\mathrm{K}_{\mathrm{h}}$ the horizontal diffusion coefficient $\left(\mathrm{K}_{\mathrm{h}}=10^{3} \mathrm{~m}^{2} / \mathrm{s}\right)$, and $\mathrm{w}$ the vertical velocity. The temperature tendency on the left-hand side of equation (2) is thus controlled from left to right by air-sea flux divergence in the mixedlayer, horizontal advection, vertical mixing at the base of the mixed-layer, horizontal diffusion, and entrainment at the base of the mixed-layer. In NEMO, entrainment is not computed explicitly but rather deduced as the residual of the heat budget (i.e., the difference between the left- hand side of equation (2) and the first four terms of the right-hand side). Complementary details of the heat budget computation in NEMO are given in Hieronymus and Nycander (2013). Units of the various terms of the budget are in ${ }^{\circ} \mathrm{C} /$ month.

\subsection{Significance test}

Due to the small number of selected events and the short duration of the simulation, it is unlikely that our samples follow a normal distribution. That is why a bootstrap method, which does not rely on a theoretical sampling distribution, is used in this paper to test the significance of our results (non-parametric test). The confidence intervals are estimated through a Monte Carlo method: we construct a thousand random composites of five individual years, with replacement, from the 26 years of simulation, and provide the $5^{\text {th }}$ and $95^{\text {th }}$ percentiles of the distribution for the $90 \%$ confidence level. In the following sections, anomalies are considered significant if they reach the $90 \%$ confidence level.

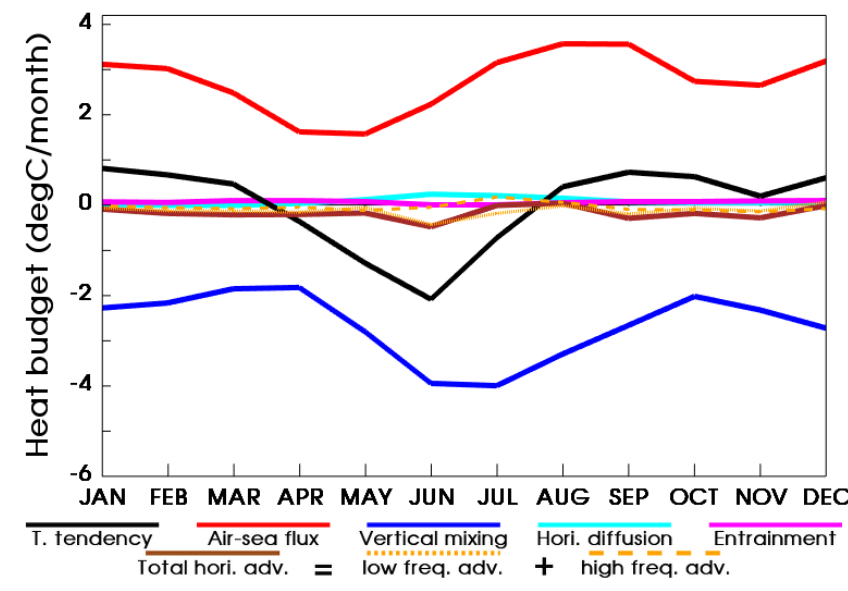

Figure 5. Mean annual cycle (average 19822007) of the mixed-layer heat budget components (in ${ }^{\circ} \mathrm{C} /$ month) averaged in the central box $\left[15^{\circ} \mathrm{W}^{\circ} \mathrm{W}, 4^{\circ} \mathrm{S}-1^{\circ} \mathrm{N}\right]$.

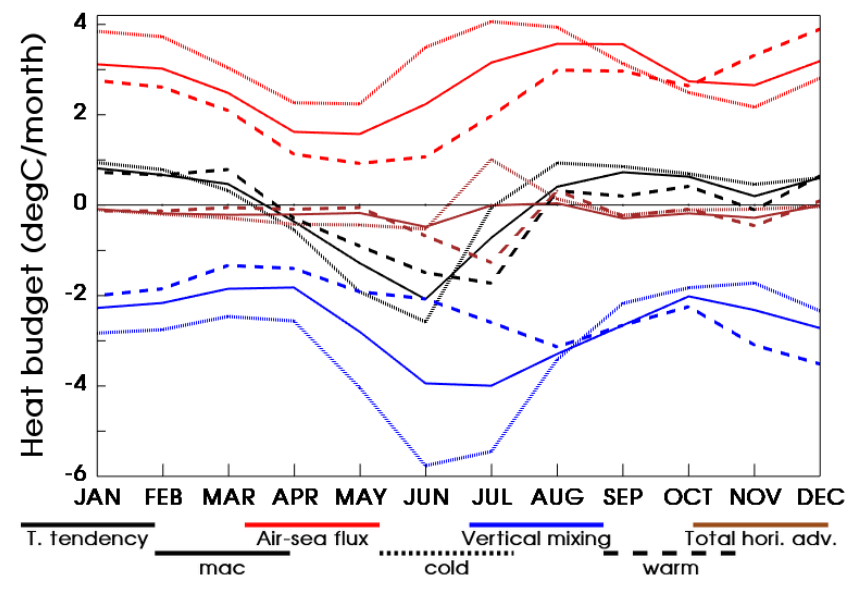

Figure 6. Mean annual cycle (MAC) in dotted line, and composites of cold (warm) ACT events years in solid line (dashed line) of the different terms of the mixed-layer heat budget in $\left({ }^{\circ} \mathrm{C} /\right.$ month) averaged in the central box $\left[15^{\circ} \mathrm{W}-6^{\circ} \mathrm{W}, 4^{\circ} \mathrm{S}-1^{\circ} \mathrm{N}\right]$.

\section{Results}

In this section, the mixed-layer heat budget is analyzed to identify the mechanisms leading to cold and warm ACT events selected in Table 2. First, the mean annual cycle of the simulation (period 1982-2007) is examined, followed by the anomalies of the mean for both the cold and warm ACT events. 


\subsection{Mean annual cycle}

In the central box, the temperature tendency (black curve in Figure 5) clearly shows a cooling period from April to July, reaching a peak value of $-2.1^{\circ} \mathrm{C} /$ month in June (or, equivalently, -60 $\left.\mathrm{W} / \mathrm{m}^{2}\right)$. This is consistent with the maximum temperature in March $\left(28^{\circ} \mathrm{C}\right)$ and the decrease of SSTs from April to August $\left(<25^{\circ} \mathrm{C}\right)$ in Figure 2a. Both SST (Figure 2a) and temperature tendency (Figure 5) indicate that the strongest cooling occurs between May and July. The timing of the cooling and the minimum temperature tendency are in accordance with previous studies based on specific years (Foltz et al. 2003; Wade et al. 2011b; Hummels et al. 2013, 2014; Schlundt et al. 2014). During the rest of the year, the temperature tendency exhibits a largely constant warming of around $0.6^{\circ} \mathrm{C} /$ month (equivalent to $+20 \mathrm{~W} / \mathrm{m}^{2}$ ).

The temperature tendency is the result of three main contributions: air-sea flux term (red curve) with a positive contribution varying from $3.7^{\circ} \mathrm{C} / \mathrm{month}\left(\sim 90 \mathrm{~W} / \mathrm{m}^{2}\right)$ in boreal autumn and winter to $1.5^{\circ} \mathrm{C} /$ month $\left(\sim 40 \mathrm{~W} / \mathrm{m}^{2}\right)$ in boreal spring, and two negative contributions, the total horizontal advection term (brown curve) varying from $-0.2^{\circ} \mathrm{C} / \mathrm{month}\left(\sim-5 \mathrm{~W} / \mathrm{m}^{2}\right)$ almost all year to $-0.5^{\circ} \mathrm{C} /$ month $\left(\sim-15 \mathrm{~W} / \mathrm{m}^{2}\right)$ in June, and the term of vertical mixing at the base of the mixedlayer (blue curve) varying from $-1.8^{\circ} \mathrm{C} /$ month $\left(\sim-60 \mathrm{~W} / \mathrm{m}^{2}\right)$ at the beginning of boreal spring to $-4.2^{\circ} \mathrm{C} /$ month $\left(\sim-100 \mathrm{~W} / \mathrm{m}^{2}\right)$ in boreal summer. The contributions of horizontal diffusion (cyan curve) and entrainment (including vertical advection; magenta curve) are weak (as in Jouanno et al. 2011a, 2011b) and so will not be discussed further. Giordani et al. (2013) showed that vertical velocities play an important but indirect role in the mixed-layer heat budget in preconditioning mixed-layers in the equatorial band, by shallowing MLDs and increasing vertical shear and stratification, thus promoting vertical mixing and surface cooling.

The term of air-sea flux, along with the amplitude and timing of the minimum of the vertical mixing term, are consistent with previous studies (Foltz et al. 2003; Peter et al. 2006; Wade et al. 2011b; Giordani et al. 2013; Hummels et al. 2013, 2014; Schlundt et al. 2014). Note that the solar radiation penetration in the ocean, represented by the parameterization of Lengaigne et al. (2007), increases the fraction of solar radiation absorbed in the mixed-layer and increases the fluxes contribution in the mixed-layer heat budget up to $67 \%$.

There is no clear agreement in the literature as to the total horizontal advection term (i.e. the sum of high and low frequency advections and both zonal and meridional advections) in the region. Schlundt et al. (2014) show a net cooling by total horizontal advection in the ACT during boreal summer. Wade et al. (2011b), using the same central box but only during 2005 and 2006, indicate that the total horizontal advection term is weak and negative during the period of formation of the ACT (from April to August) and positive afterwards. Foltz et al. (2003) and Hummels et al. (2013, 2014 ) indicate that, at $10^{\circ} \mathrm{W}$, the total horizontal advection term is almost zero during the period of formation of the ACT and positive afterwards. In Peter et al. (2006), Jouanno et al. (2011a, 2011b) and Giordani et al. (2013) the sign of the total horizontal advection term depends on the location and the season. In our simulation, the total horizontal advection term is negative west of $5^{\circ} \mathrm{W}$ and positive east of $5^{\circ} \mathrm{W}$ and, as in the literature, its intensity depends on the season (not shown).

These differences of advection may be related to equatorial waves (mainly TIWs). Many studies (Foltz et al. 2003; Jochum and Murtugudde 2006; Giordani et al. 2013; Jouanno et al. 2013; Hummels et al. 2013, 2014) demonstrate that these waves strongly contribute to the warming of the ACT near the equatorial front. In our simulation, the effect of equatorial waves is estimated by the high frequency advection (orange dashed curve in Figure 5). This term is computed as the residual between the total horizontal advection computed online by the model and the low frequency advection computed using monthly data. In the model, the role of high frequency advection is negligible and total advection is essentially due to low frequency advection (orange dotted curve in Figure 5). The weak effect of high frequency advection may result from an underrepresentation of TIWs. As simulated TIWs are influenced by horizontal resolution (e.g. Jochum et al. 2005), it is possible that a higher horizontal resolution would enhance eddy advection, moving the limit of positive advection effects westward. However, the central box is only partially influenced by the 
equatorial front and the wave contributions to the mixed-layer heat budget could be relatively weak on average over this box.

Given these limitations, the mean annual cycle of the mixed-layer heat budget is in reasonable agreement with the literature, allowing the analysis of its interannual variability of the ACT. In the following sections, the results are often compared to "neutral years"; i.e., to years following the mean annual cycle.

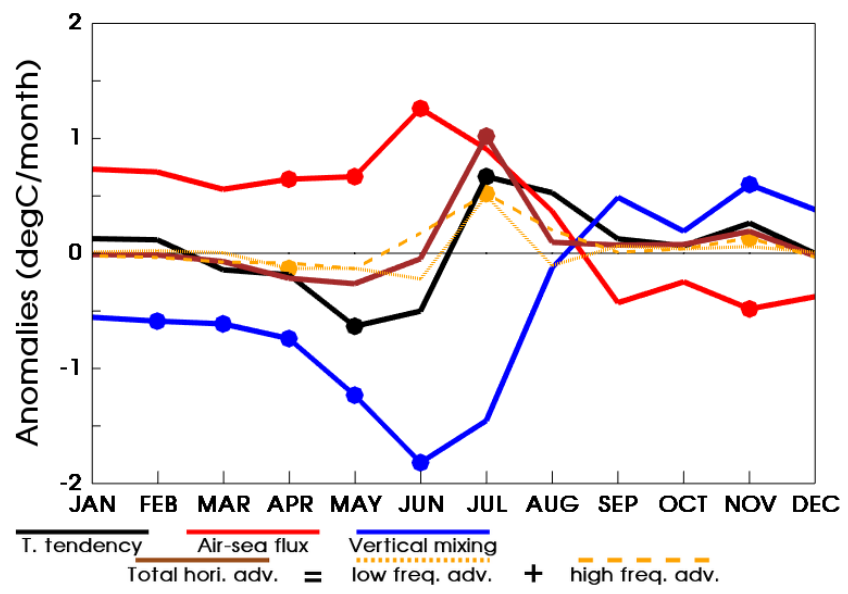

Figure 7. Cold ACT events anomalies to the mean annual cycle of the mixed-layer heat budget terms (in ${ }^{\circ} \mathrm{C} /$ month) averaged in the central box $\left[15^{\circ} \mathrm{W}-6^{\circ} \mathrm{W}, 4^{\circ} \mathrm{S}-1^{\circ} \mathrm{N}\right]$. Dots indicate the significance at the $90 \%$ confidence level.

\subsection{Cold ACT events}

During cold ACT events, the temperature tendency and its three main contributions differ in comparison to those of the mean annual cycle (Figure 6). From March to June, the temperature tendency decreases in response to a very strong cooling due to the vertical mixing term, and a small cooling due to the total horizontal advection term (which still contributes to a negative temperature tendency). During this period, the increased air-sea flux term (with a positive contribution to the temperature tendency) limits the cooling of the other terms. An abrupt change occurs between June and July, leading to the reversal of the sign of the temperature tendency (less cooling). This is primarily due to the total horizontal advection term, while air-sea flux and vertical mixing terms play a minor role. After July, the temperature tendency increases further, mainly due to weaker cooling by the vertical mixing term. Consequently, during cold ACT events, the minimum of the temperature tendency $\left(-2.5^{\circ} \mathrm{C} /\right.$ month) in June is smaller (more negative) than in the mean annual cycle $\left(-2.0^{\circ} \mathrm{C} /\right.$ month $)$, and the temperature tendency becomes positive earlier than in the mean annual cycle; i.e., in July rather than August. Finally, the total horizontal advection term, which is weak during the cooling phase between March and June, plays a leading role in stopping the cooling of the ACT in June-July until its warming in July-August.

In order to better understand the processes at work during cold ACT events, the heat budget anomalies (computed monthly with respect to the mean annual cycle) of the composited five cold ACT events were analyzed in detail (Figure 7). Temperature tendency anomalies are negative from March to June, with a minimum of $-0.63^{\circ} \mathrm{C} / \mathrm{month}$ in May. Negative temperature tendency anomalies result mainly from negative anomalies of the vertical mixing term (significant from January to June) and, to a lesser extent, from negative anomalies of the total advection term (nonsignificant). These anomalies are partially balanced by anomalies of the air-sea flux term (significant from April to June).

We have shown that the air-sea flux term is increased during cold ACT events. This is primarily due to a reduced latent heat flux $\left(10 \mathrm{~W} / \mathrm{m}^{2}\right.$ to $15 \mathrm{~W} / \mathrm{m}^{2}$ from January to August) and secondarily due to an increased solar flux in April $\left(10 \mathrm{~W} / \mathrm{m}^{2}\right)$ and May $\left(5 \mathrm{~W} / \mathrm{m}^{2}\right)$. These phenomena and their intensities are confirmed in several reanalyses (ERA-I, ICOADS, NCEP Reanalysis 2, 
TropFlux). The enhanced solar flux appears to be due mainly to reduced cloud cover (not shown). The reduced latent heat flux is surprising given that the wind intensification during cold ACT events should enhance evaporation and consequently act as a positive feedback by decreasing the mixed-layer temperature. A reduced latent heat flux has already been observed in several studies (Foltz et al. 2003; Foltz and McPhaden 2006; Marin et al. 2009), which attributed the latent heat flux anomalies to SST anomalies. Foltz and McPhaden (2006) showed that variations of the latent heat flux in the ACT are strongly correlated to variations of the vertical humidity gradient, which is mainly influenced by SST fluctuations. Therefore, it appears that latent heat flux anomalies are a consequence of SST anomalies, which affect the vertical humidity gradient.

In the mean annual cycle, the total horizontal advection term plays only a minor role in the mixed-layer temperature tendency. In July however, during cold ACT events, significant anomalies of the total horizontal advection term prevail and coincide with the reversal of the sign of the temperature tendency anomalies (Figure 7). The origin of these horizontal advection anomalies is now investigated in order to understand the role played by the SEC, the temperature gradient and the equatorial waves. The central box experiences the greatest temperature anomalies (Figure 8a), strengthening the temperature gradient along the equator (with colder temperatures around $10^{\circ} \mathrm{W}$ than in the east and a stronger equatorial front). Perez et al. (2012) showed that variance of TIWs is elevated when the ACT is anomalously cold, and therefore enhance eddy advection. This appears to be partially responsible for the anomalies of the total horizontal advection term, as the highfrequency advection (including all types of equatorial waves) abnormally warms the central box by $0.5^{\circ} \mathrm{C} /$ month (Figure 7 , orange dashed curve). As discussed previously, a higher horizontal resolution allows a better representation of TIWs and would probably enhance high frequency advection anomalies. The low-frequency advection also presents a positive anomaly of $0.5^{\circ} \mathrm{C} / \mathrm{month}$ (orange dotted curve). During cold events, the SEC is enhanced between January and June, and is then slowed from August until the end of the year (not shown). Consequently, in July the low frequency advection anomalies are due solely to the stronger zonal temperature gradient compared to neutral years. Therefore, this stronger horizontal temperature gradient compared to neutral years leads to significantly positive anomalies of the total horizontal advection term in July $\left(1^{\circ} \mathrm{C} / \mathrm{month}\right)$. These positive total horizontal advection anomalies initiate the ACT's decrease in intensity.

The rapid change of the velocity anomalies of the SEC (from enhanced to reduced current) in boreal summer is particularly interesting, as downwelling Kelvin and Rossby waves are known to affect the zonal surface current (e.g. Delcroix et al. 1991; Lien et al. 1995) and to deepen the mixedlayer, influencing the total horizontal advection term. We found indications that this mechanism is active in some years. For example, in 1997, two eastward-propagating positive SSH anomalies along the equator, indicative of downwelling Kelvin waves (the first in February and the second in May; not shown), seem to trigger or enhance (Delcroix et al. 1991; Lübbecke and McPhaden 2012; Lübbecke et al. 2014) westward-propagating positive SSH anomalies along $4^{\circ} \mathrm{S}$, indicative of a downwelling Rossby wave (passing through the central box in July; not shown). In other cold events, however, the eastward-propagating positive SSH anomalies along the equator in May are present, but there is no clear indication of westward-propagating positive SSH anomalies between June and August.

In order to understand the link between local mixed-layer temperature anomalies and wind anomalies (parameters used for the classification), we now examine the spatial and temporal distribution of the mixed-layer properties with Hovmöller diagrams (Figure 8). Significant negative mixed-layer temperature anomalies are present from March to August between $30^{\circ} \mathrm{W}$ and $5^{\circ} \mathrm{E}$, with a minimum value of $-1.5^{\circ} \mathrm{C}$ in June at $10^{\circ} \mathrm{W}$ (Figure 8a). Accordingly, the cold tongue temperature falls down to $25^{\circ} \mathrm{C}$ (a threshold used by Caniaux et al. (2011) to define the cold tongue) earlier than during neutral years. Anomalies of the vertical mixing term are significant along the equator from February to July and reach a minimum of $-1.5^{\circ} \mathrm{C} /$ month in June at $10^{\circ} \mathrm{W}$ (Figure $8 \mathrm{~b}$ ). This is consistent with the location of the minimum of temperature anomalies (Figure 8a). 

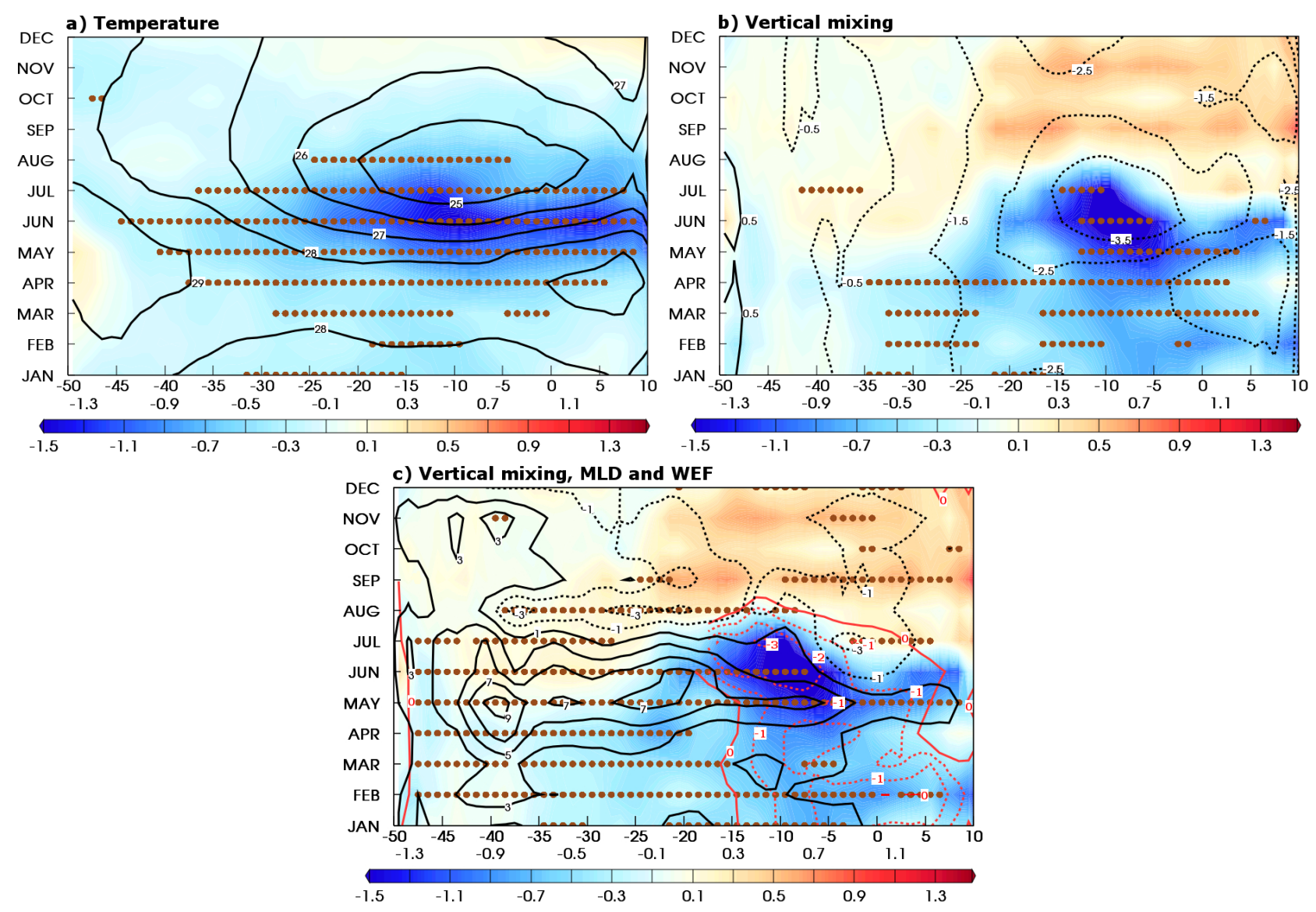

Figure 8. Time versus longitude Hovmöller composite diagrams for cold ACT events (latitude averaged over $4^{\circ} \mathrm{S}-1^{\circ} \mathrm{N}$ ) extending from $50^{\circ} \mathrm{W}$ to $10^{\circ} \mathrm{E}$. a) Temperature mean annual cycle (average 1982-2007) in isoline (every $1^{\circ} \mathrm{C}$ ), temperature anomalies in color (in ${ }^{\circ} \mathrm{C}$ ), and significance at the $90 \%$ confidence level (dots). b) Vertical mixing mean annual cycle (average 1982-2007) in isoline (every ${ }^{\circ} \mathrm{C} /$ month), vertical mixing anomalies in color (in ${ }^{\circ} \mathrm{C} / \mathrm{month}$ ), and significance at the $\mathbf{9 0 \%}$ confidence level (dots). c) Vertical mixing anomalies in color (in ${ }^{\circ} \mathrm{C} /$ month), mixed-layer depth anomalies (where MLDs are shallower than $20 \mathrm{~m}$ ) in red isoline (every $1 \mathrm{~m}$ ), WEF anomalies in black isolines (every $2 * 10^{-6} \mathrm{~m}^{3} / \mathrm{s}^{3}$ ), and significance of WEF anomalies at the $90 \%$ confidence level (dots).

The surface wind stress is often proposed to explain the interannual variability of the ACT (e.g. Marin et al. 2009; Jouanno et al. 2013). However, the wind energy flux (WEF $\left.=\tau_{x} \cdot u+\tau_{y} \cdot v\right)$ is a much more relevant parameter in explaining the spatial and temporal variability of cooling by vertical mixing, through the triggering of Kelvin waves and the modulation of the vertical shear in subsurface (Giordani et al. 2013). The WEF represents the flux of kinetic energy transferred from the atmosphere into the ocean through the air-sea surface. When surface wind stress and surface currents have the same (opposite) direction, the atmosphere provides (withdraws) energy to (from) the ocean and consequently increases (decreases) the oceanic kinetic energy (Giordani and Caniaux 2011; Giordani et al. 2013; Voldoire et al. 2014). The WEF anomalies superimposed on the anomalies of cooling by vertical mixing (Figure 8c) bring up a zonal and time shift between the maximum of the WEF anomalies $\left(10^{-5} \mathrm{~m}^{3} / \mathrm{s}^{3}\right)$ at $40^{\circ} \mathrm{W}$ in May and the anomalies of cooling by vertical mixing at $10^{\circ} \mathrm{W}$ (where the WEF anomalies reach $2 \times 10^{-6} \mathrm{~m}^{3} / \mathrm{s}^{3}$ ) in May, June and July.

The WEF enhancement in the WEA can generate SST anomalies in the ACT by exciting upwelling Kelvin waves (e.g. Adamec and O'Brien 1978; Houghton 1989; Marin et al. 2009). These eastward-propagating waves will reach the central box about a month later, forcing a shoaling of the thermocline and the MLD (e.g. Lien et al. 1995). This may explain the time shift between the strongest WEF anomalies (in May) and the strongest anomalies of cooling by vertical 
mixing (in June). Analysis of the SSH showed an upwelling Kelvin wave passing through the central box at the end of April (not shown) in all cold events, enhancing the cooling by vertical mixing in April and May (Figure 8c). In 1997, another upwelling Kelvin wave passes through the central box in June. In other cold events, however, there is no clear indication of wave propagation in this period. We conclude that, while the WEF enhancement in the WEA remotely triggers a cooling by vertical mixing in the ACT, additional local processes are at work to amplify and extend this strong cooling.

Locally, the cooling by vertical mixing is partly influenced by the production of TKE, which is mainly controlled by the vertical shear between the SEC and the EUC. Similarly to Brandt et al. (2014), we analyzed the velocity of the EUC in our model. Cold ACT events are associated with a strengthening of the EUC as in previous studies (Góes and Wainer 2003; Hormann and Brandt 2007; Brandt et al. 2014) but in our simulation the EUC velocity anomalies are not significant (as in Jouanno et al. 2011b; not shown). On the other hand, the WEF locally influence the oceanic kinetic energy, and therefore the intensity of the SEC. The combined effects of the enhanced currents increase the vertical shear in the central box (Figure 9a; we focus here on June, when the anomalies of cooling by vertical mixing are the strongest).

MLD and the vertical temperature gradient are also key parameters for the cooling by vertical mixing (see equation 2). The vertical response to the WEF anomalies is the enhancement of the trans-equatorial circulation, with increased upward velocities south of the equator and increased downward velocities north of the equator (Figure 9). As suggested by Giordani et al. (2013), the variations of the vertical velocities reduce the MLD and increase the stratification (Figure 9b). The increased stratification can reduce the effect of the enhanced vertical shear on the production of TKE. The Richardson number $\left(\mathrm{Ri}=\left[\mathrm{g} / \rho_{0} \times \partial \rho / \partial \mathrm{z}\right] /\left[\partial \mathrm{U}_{\mathrm{h}} / \partial \mathrm{z}\right]\right)$, comparing the stratification and the vertical shear, indicates that the shear anomalies overcome the stratification anomalies (Figure 9c). Weak Richardson number values and negative anomalies around the MLD reveal an enhanced production of TKE by Kelvin-Helmholtz instabilities. As a result, the vertical mixing at the base of the mixed-layer is increased, extracting more heat.

Here it should be reiterated that ACT events were selected according to the spring wind. Therefore, it is not surprising that the WEF emerges as a common driver of the cooling on the years considered. However, as the timing and intensity of the spring zonal wind stress anomalies in the WEA are different from year to year and from dataset to dataset, the selection criterion on the zonal wind stress was a test of the sign of the zonal wind stress rather than a criterion for its intensity. Therefore, the set-up did not fully impose the role of the WEF anomalies in the ACT at the beginning of boreal summer or their influence on cooling by vertical mixing, causing the formation of cold ACT events.

In summary, cold ACT events are characterized by enhanced cooling by vertical mixing, which prevails over increased warming air-sea heat fluxes from March to June. Enhanced production of TKE, along with a strong vertical temperature gradient and shallow MLDs, promote the cooling of the mixed-layer by vertical mixing. In July, anomalies of the total horizontal advection term become sharply positive and damp the cumulative effect of the two leading terms of the mixed-layer heat budget. This abrupt change is attributed to the strong SST anomalies within the ACT, which change the horizontal temperature gradient in the following way: i) they reinforce the equatorial front, which can lead to enhanced equatorial waves, increasing the warming by high frequency advection; and ii) they reverse the zonal temperature gradient, which is westward until June and eastward in July, increasing the warming by low frequency advection. This can be viewed as a negative feedback to the local vertical mixing effects. Both vertical mixing anomalies and total horizontal advection anomalies appear to be affected by the propagation of Kelvin and Rossby waves. 

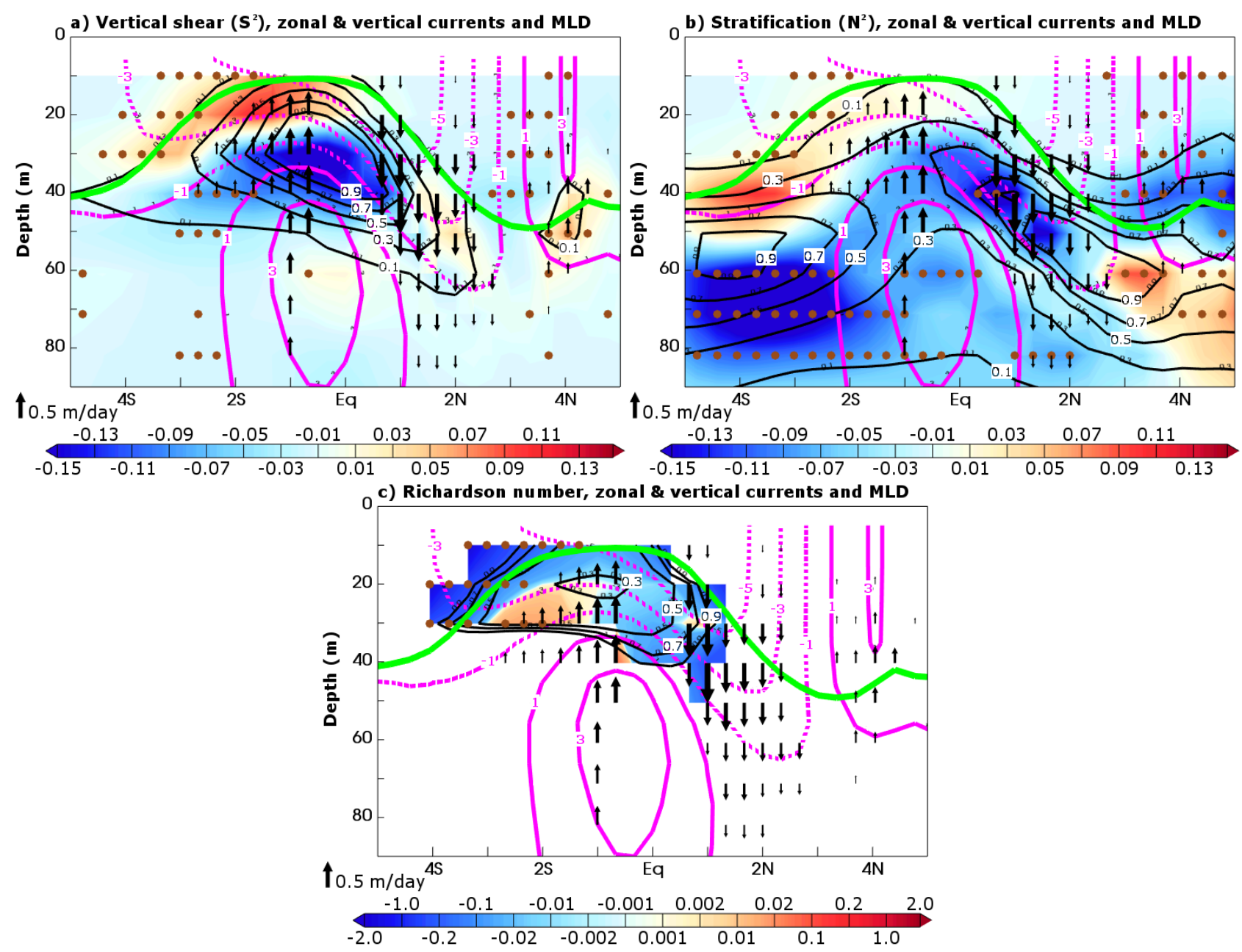

Figure 9. Meridional vertical cross-section in June for cold ACT events (longitude averaged over $15^{\circ} \mathrm{W}-6^{\circ} \mathrm{W}$ ). a) vertical shear of the horizontal currents $S^{2}$ (June average during 19822007) in black isoline (every $0.2 * 10^{-3} \mathrm{~s}^{-2}$ from 0 to 1 ), $\mathrm{S}^{2}$ anomalies in color (in $10^{-3} \mathrm{~s}^{-2}$ ), and significance of $\mathrm{S}^{2}$ anomalies at the $90 \%$ confidence level (dots). b) same as a) for the stratification $\mathrm{N}^{2}$. c) Richardson number Ri (June average during 1982-2007) in black isoline (every 0.2 from 0 to 1 ), $\mathrm{Ri}$ anomalies (where the $\mathrm{Ri}$ is smaller than 2) in color (logarithmic scale), and significance of $\mathrm{Ri}$ anomalies at the $\mathbf{9 0 \%}$ confidence level (dots). Purple isolines (every $2 * 10^{-1} \mathrm{~m} / \mathrm{s}$ ) represent the zonal currents during cold ACT events; solid (dashed) lines correspond to eastward (westward) currents. Vectors represent the anomalies of vertical velocities (in $\mathrm{m} /$ day) significant at the $\mathbf{9 0 \%}$ confidence level. The green curve represents the MLD during cold ACT events.

\subsection{Warm ACT events}

During warm ACT events (dashed curves in Figure 6), the contribution of the air-sea flux term is weak in comparison to the mean annual cycle (and in comparison to cold ACT events), and the vertical mixing term is less negative than in the mean annual cycle from January to August. Importantly, the cooling by the total horizontal advection term from May to July allows the minimum of the temperature tendency $\left(-1.5^{\circ} \mathrm{C} / \mathrm{month}\right)$ to be shifted to July, i.e. one month later than in the mean annual cycle and during cold ACT events.

The heat budget anomalies of the five warm ACT events (Figure 10) indicate that temperature tendency anomalies (black curve) are positive from February to June, with a significant maximum value of $0.58^{\circ} \mathrm{C} /$ month reached in June. During the same period, anomalies of the vertical mixing term (blue curve) present significant positive values, while anomalies of the air-sea flux term (red curve) are negative. As for cold ACT events, the temperature tendency anomalies are mainly 
controlled by the anomalies of the vertical mixing term. Anomalies of the air-sea flux term are due primarily to negative latent heat flux anomalies from May to July $\left(-6 \mathrm{~W} / \mathrm{m}^{2}\right.$ to $\left.-16 \mathrm{~W} / \mathrm{m}^{2}\right)$ and secondly to solar flux anomalies from February to June $\left(-6 \mathrm{~W} / \mathrm{m}^{2}\right.$ to $-9 \mathrm{~W} / \mathrm{m}^{2}$; not shown). As during cold ACT events, latent heat flux anomalies seem to be the consequences of SST anomalies, and the solar heat flux reduction is linked to an increased cloud cover (not shown).

The weaker spring cooling compared to neutral years modifies the temperature gradient along the equator and causes significantly strong negative anomalies of the total horizontal advection term $\left(-1.3^{\circ} \mathrm{C} /\right.$ month). As during cold ACT events, both high and low frequency advection anomalies $\left(-0.45^{\circ} \mathrm{C} /\right.$ month and $-0.85^{\circ} \mathrm{C} /$ month, respectively) contribute to the horizontal advection anomalies (Figure 10). Symmetrically to cold ACT events, an eastward-propagating negative SSH anomaly along the equator is present in May during warm ACT events, indicative of an upwelling Kelvin wave (not shown), followed by a westward-propagating negative $\mathrm{SSH}$ anomaly along $4^{\circ} \mathrm{S}$, indicative of an upwelling Rossby wave (passing through the central box in August; not shown). As cold ACT events, these waves influence the velocity anomalies of the SEC (which is symmetrical between the cold and warm events; not shown) and the MLD. As explained previously, we hypothesize that high frequency advection is underestimated at the model resolution, such that its cooling effect could be larger than estimated by our model. It is interesting to note that beyond July, the anomalies of the total horizontal advection term increase (i.e. less cooling), while cooling is further maintained by a weaker air-sea flux term (i.e. less warming) until October. This sequencing of processes results in a later ACT development during warm ACT events compared to cold ACT events or even neutral years.

The warm temperature anomalies are significant from March to August between $35^{\circ} \mathrm{W}$ and $0^{\circ} \mathrm{E}$, and a maximum value of $1.5^{\circ} \mathrm{C}$ is reached in July at $15^{\circ} \mathrm{W}$ (Figure $11 \mathrm{a}$ ). Unlike during cold ACT events, the temperature anomalies east of $0^{\circ} \mathrm{E}$ are not significant. This might explain why the low frequency advection anomalies are stronger during warm ACT events compared to cold ACT events: east of the central box the SST anomalies are weaker during warm ACT events, generating stronger zonal temperature gradient anomalies (note that during cold and warm ACT events, the velocity anomalies of the SEC are almost zero in July; not shown). The temperature anomalies rapidly decrease after July and are followed by significantly cold anomalies in November and December.

The anomalies of the vertical mixing term are strongly positive (i.e. less mixing) and significant from April to August in the band $20^{\circ} \mathrm{W}-5^{\circ} \mathrm{W}$ (Figure 11b). They reach a maximum of $1.5^{\circ} \mathrm{C} /$ month in June and July between $15^{\circ} \mathrm{W}$ and $5^{\circ} \mathrm{W}$. During warm ACT events, the strongest WEF anomalies $\left(-9^{*} 10^{-6} \mathrm{~m}^{3} / \mathrm{s}^{3}\right.$ at $\left.20^{\circ} \mathrm{W}\right)$ appear very close to the strongest anomalies of the vertical mixing term $\left(-2^{\circ} \mathrm{C} /\right.$ month at $\left.10^{\circ} \mathrm{W}\right)$ and occur at the same time (June). Symmetrically to cold ACT events, a downwelling Kelvin wave passes through the central box at the end of April (not shown) and triggers a deepening of the thermocline and the MLD, creating positive anomalies of the vertical mixing term in May (i.e., less mixing; see Figure 11c). As in cold ACT events, this remote effect of the WEF is amplified by its local effect: modulation of the vertical velocity, influencing the MLD and the vertical temperature gradient, and a reduced vertical shear of horizontal current (slowed EUC and SEC; not shown). The vertical shear anomalies overcome the reduced stratification (due to the decreased vertical velocity) and increase the Richardson number (i.e. decreased production of TKE). The combined effects of a small production of TKE, a weak vertical gradient and a deep mixed-layer fail to produce intense cooling by vertical mixing.

We thus conclude that cold and warm ACT events involve the same leading processes: vertical mixing, air-sea heat fluxes and horizontal advection. Cold ACT events initiate and develop through intense cooling by vertical mixing, resulting from intense WEF anomalies during a short period of time (May-June). This explains why this category of events develops rapidly. Horizontal advection tends to damp cold ACT events in July, just after the maximum cooling is reached. On the other hand, warm ACT events are characterized by a weak cooling by vertical mixing (even though this process remains the leading term of the mixed-layer heat budget) due to the effect of a 
weaker WEF on the oceanic circulation. However, the local warm anomalies favor horizontal advection of relatively colder waters, which extends the cooling period. As a result, warm ACT events are less intense due to weaker cooling by vertical mixing but are lengthened by horizontal advection.

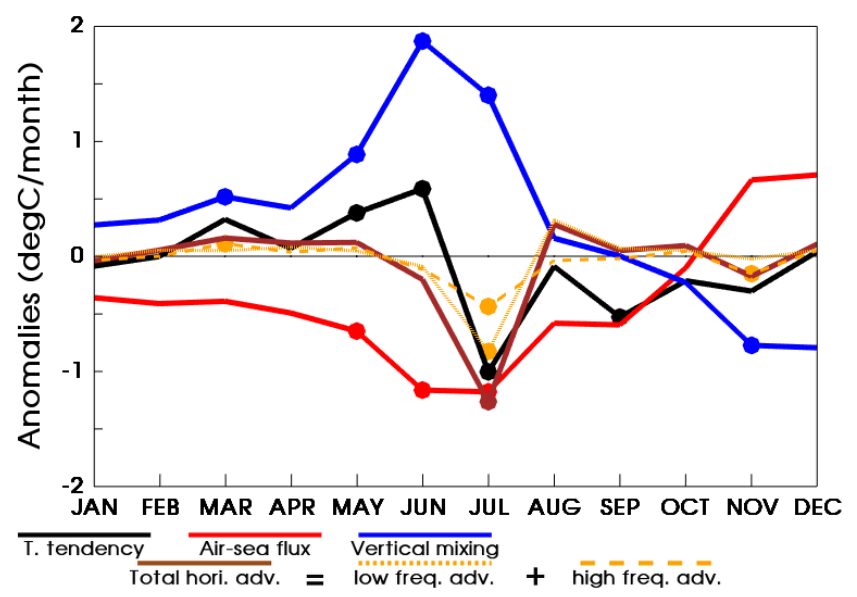

Figure 10. Same as Figure 7 for warm ACT events.
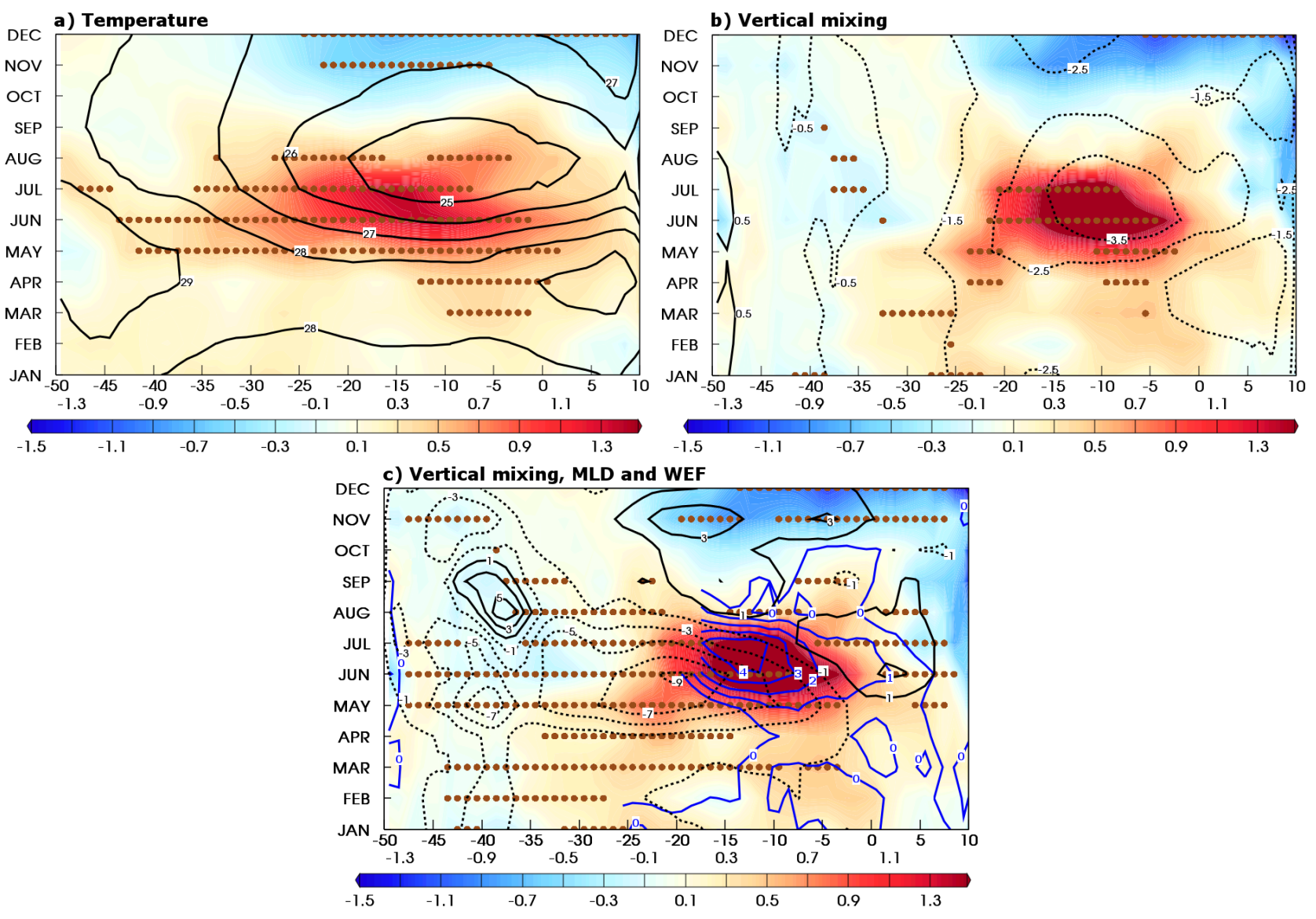

Figure 11. Same as Figure 8 for warm ACT events.

\section{Summary and discussion.}

In this study, the mechanisms generating anomalous cold and warm canonical Atlantic cold tongue (ACT) events (i.e. sea surface temperature anomalies preceded by wind stress anomalies of the same sign) are investigated using a mixed-layer heat budget computed with a forced ocean 
general circulation model. The global model, forced with the COREv2 interannually varying forcing, reproduces the interannual variability of the ACT quite well. The coldest and warmest events of the last 26 years (1982-2007) were selected by using a classification based on sea surface temperatures (SSTs) and zonal wind stress anomalies. A cold (warm) ACT event is selected when there is a negative (positive) SST anomaly at the center of the equatorial Atlantic in late spring, preceded by a negative (positive) zonal wind stress anomaly to the west. This classification was applied to ten datasets derived from observations and/or reanalyses; the selected events did not depend on a single dataset or model so as to ensure the robustness of our results. With this methodology, five cold and five warm ACT events were selected. The simulation was able to produce the selected events correctly. The combination of this robust classification and a comprehensive mixed-layer heat budget analysis allowed the main physical processes of the upper ocean driving cold and warm ACT events to be highlighted.

The mean annual cycle of the heat budget obtained from the model is consistent with previous studies based on a small number of years (Foltz et al. 2003; Peter et al. 2006; Jouanno et al. 2011b; Wade et al. 2011b; Giordani et al. 2013; Hummels et al. 2013, 2014; Schlundt et al. 2014). It shows that the temperature tendency is the result of three main processes, in decreasing order of importance: vertical mixing, air-sea heat fluxes and horizontal advection. Our study confirms the dominant role of vertical mixing at the base of the mixed-layer in the spring cooling of the ACT.

With regard to interannual variability, our results further indicate that vertical mixing remains the main process controlling anomalies leading to cold and warm canonical ACT events, a result already suggested by Wade et al. (2011b), based on only three years (but particularly contrasted in terms of timing and intensity of cooling).

Note that during both cold and warm ACT events, anomalies of the cooling by vertical mixing are significant in March. The correlation between these anomalies in March and SST anomalies in June has been computed over the period 1982-2007. We found a high correlation of 0.67 , significant at the $99 \%$ confidence level. This may indicate that early spring vertical mixing anomalies could be used as a predictor to forecast SST anomalies during the formation of the ACT at a two-month lead-time.

A specific diagnostic was used to characterize the anomalies of the vertical term in the cold and warm ACT events: namely, the wind energy flux (WEF), a measure of the coupling between the atmosphere and the oceanic upper-layers. The WEF increases when the surface wind stress and the surface currents have the same direction, thus favoring the vertical current shear within the SEC and the increase of vertical mixing at the base of the shallow mixed-layers of the ACT. The composites of the five cold and five warm ACT events showed that the anomalies of the vertical mixing term are clearly related to the WEF anomalies. At the end of the spring of cold (warm) ACT events, the WEF anomalies trigger an upwelling (a downwelling) Kelvin wave, forcing a shoaling (deepening) of the thermocline and the mixed-layer depth (MLD). This creates strong anomalies of the vertical mixing term. This remote effect is further amplified by the local response to the WEF forcing: increased (decreased) production of TKE, stronger (weaker) vertical temperature gradient and shallowed (deepened) MLD. Anomalies of the vertical mixing cooling, created through these mechanisms, are partially balanced by air-sea flux anomalies. The air-sea flux feeds back by reducing (increasing) the latent heat flux and increasing (reducing) the solar heat flux. However, anomalies of cooling by vertical mixing prevail over air-sea flux anomalies, allowing the development of negative (positive) SST anomalies from March to June during cold (warm) ACT events.

Another important difference between cold and warm ACT events is the duration of the cooling. During cold ACT events, a strong warming by horizontal advection contributes to reversing the sign of the temperature tendency from negative to positive and thus to stopping the cooling of the ACT in July and even to warming the ACT in August. In contrast, during warm ACT events, a strong cooling by horizontal advection arises in July and extends the temperature cooling until August, thus partially compensating for the less intense cooling due to weaker vertical mixing. Both low and high frequency advection contribute to this compensating effect. Although the effect 
of high frequency advection is probably underestimated in our model, this would not alter the sign of advection. During both cold and warm ACT events, these horizontal advection anomalies are influenced by temperature gradient (caused by the SST anomalies) and by Rossby waves.

The role of advection has been suggested by Burls et al. (2012) and Lübbecke et al. (2014) to explain the interannual variability of the ACT. Here we demonstrate the importance of horizontal advection, which stops the cooling period during cold ACT events and extends the cooling period during warm ACT events. Consequently, horizontal advection, which plays a minor role in the formation of the ACT itself, controls the duration of the cooling period in boreal summer.

As all of our results are based on a model study, they may include errors. For example, SST anomalies are stronger in the simulation than in other datasets, implying an overestimation of the anomalies of the heat budget terms. However, we have a high level of confidence in the realism of our simulation because the mean annual cycle of the mixed-layer heat budget computed with our model is in agreement with the literature (based on model or observations). Further, while SST anomalies are slightly overestimated, their timing is good, showing that the mechanisms at work have the correct time-scale. This overestimation could be explained by the fact that the model is forced, and thus damping processes by the ocean-atmosphere coupling could be underestimated. Additionally, our model is an interesting tool for estimating the mixed-layer heat budget anomalies, since the errors in estimating the heat budget from observations alone would probably have been at least as large as they are in our model.

As the selected ACT events are in common agreement between several datasets in our classification, many of our model results (concerning SST, heat fluxes, cloud cover, WEF, vertical shear of horizontal current,...) have been confirmed by these datasets.

Antagonism between the mixing and advection processes refers to the delayed oscillator often used to describe the ENSO cycle (Suarez and Schopf 1988; Battisti and Hirst 1989). In such simplified models, the system oscillates under a rapid positive feedback and a slow negative feedback. In the case of the Atlantic cold tongue, the mixed-layer heat budget performed in this study suggests that positive WEF anomalies during cold events generate intense cooling by vertical mixing, representing the rapid positive feedback. SST anomalies modulate the SST gradients, triggering advection anomalies, which damps not only SST anomalies but also negative WEF anomalies favoring weak cooling by vertical mixing. Both the readjustment of water masses and the weak WEF/vertical mixing represent slow negative feedback. This result is consistent with the advective-reflective oscillator, in which the zonal advection tends to warm the oceanic upper-layers in the equatorial Pacific (Picaut et al. 1997; Clarke et al. 2000).

In this study, we focus on cold and warm canonical ACT, but there are sources of interannual variability other than the wind. In particular, the deep ocean or the ocean subsurface (under the mixed-layer) are other factors that can influence the ACT formation. For example, Richter et al. (2013) suggested that non-canonical ACT events could be controlled by meridional advection under the mixed-layer. Non-canonical ACT events are less frequent, and thus our compositing methodology could not be used in this case. To address this question, we performed a careful analysis of the heat budget during some of these events (not shown). Our first results suggest that the same mixed-layer processes are involved during canonical and non-canonical ACT events but that their intensity, timing and location are different.

Additionally, our classification focuses on the location of maximum equatorial cooling (around $10^{\circ} \mathrm{W}$ ). Based on this classification, we could not find evidence of a link between the intensity of the cooling at $10^{\circ} \mathrm{W}$ and either the westward extension of the cooling along the Equator or the southeastern tropical Atlantic. The processes linking the interannual variability in these two regions must be investigated in further studies.

Acknowledgments. The authors gratefully acknowledge comments of the anonymous reviewers that led to significant improvements. The research leading to these results has received funding by the European Union's Seventh Framework Programme FP7 PREFACE under grant agreement 603521. 


\section{References}

Adamec D, O'Brien JJ (1978) The seasonal upwelling in the Gulf of Guinea due to remote forcing. J. Phys. Oceanogr., 8(6):1050-1060. doi: 10.1175/1520-0485(1978)008<1050:TSUITG >2.0.CO;2

Balmaseda MA, Mogensen K, Molteni F, Weaver AT (2010) The NEMOVAR-COMBINE ocean re-analysis. COMBINE Technical report No. 1

Balmaseda MA, Mogensen K, Weaver AT (2013) Evaluation of the ECMWF ocean reanalysis system ORAS4. Q.J.R. Meteorol. Soc., 139:1132-161. doi: 10.1002/qj.2063

Battisti DS, Hirst AC (1989) Interannual variability in a tropical atmosphere ocean model - Influence of the basic state, ocean geometry and nonlinearity. Journal of the Atmospheric Sciences, 46(12):1687-1712. doi: 10.1175/15200469(1989)046<1687:IVIATA>2.0.CO;2

Blanke B, Delecluse P (1993) Variability of the tropical Atlantic ocean simulated by a general circulation model with two different mixed-layer physics. J. Phys. Oceanogr., 23:1363-1388. doi: 10.1175/15200485(1993)023<1363:VOTTAO >2.0.CO;2

Brandt P, Funk A, Tantet A, Johns WE, Fischer J (2014) The equatorial undercurrent in the central Atlantic and its relation to tropical Atlantic variability. Clim. Dyn., 43(11):2985-2997. doi: 10.1007/s00382-014-2061-4

Burls NJ, Reason CJC, Penven P, Philander SG (2012) Energetics of the tropical Atlantic zonal mode. J. Climate, 25:7442-7466. doi: 10.1175/JCLI-D-11-00602.1

Cabanes C, Grouazel A, Von Schuckmann K, Hamon M, Turpin V, Coatanoan C, et al. (2013) The CORA dataset: validation and diagnostics of in-situ ocean temperature and salinity measurments. Ocean Sci., 9(special issue):1-18. doi: 10.5194/os-9-1-2013

Caniaux G, Giordani H, Redelsperger JL, Guichard F, Key E, Wade M (2011) Coupling between the Atlantic cold tongue and the West African Monsoon in boreal spring and summer. J. Geophys. Res., 116:C04003. doi: 10.1029/2010JC006570

Carr ME, Fredrichs MAM, Schmeltz M, Aita MN, Antoine D, Arrigo KR, et al. (2006) A comparison of global estimates of marine primary production from ocean color. Deep Sea Res. II, 53:741-770. doi: 10.1016/j.dsr2.2006.01.028

Clarke AJ, Wang JG, Van Gorder S (2000) A simple warm-pool displacement ENSO model. J. Phys. Oceanogr., 30(7):1679-1691. doi: 10.1175/1520-0485(2000)030<1679:ASWPDE > 2.0.CO;2

Colin C (1989) Sur la variabilité dans le Golfe de Guinée. Nouvelles considérations sur les mécanismes d'upwelling. Ph.D. thesis, Muséum National d'Histoire Naturelle de Paris

Dai A, Trendberth KE (2002) Estimates of freshwater discharge from continents: latitudinal and seasonal variations. J. Hydrometeorol., 3:660-687. doi: 10.1175/1525-7541(2002)003<0660:EOFDFC $>2.0 . C O ; 2$

Danabasoglu G, Yeager SG, Bailey D, Behrens E, Bentsen M, Bi D, et al. (2014) North Atlantic simulations in the Coordinated Ocean-sea ice Reference Experiments phase II (CORE-II). Part I: Mean states. Ocean Modelling, 73:76-107. doi: 10.1016/j.ocemod.2013.10.005

de Boyer Montégut C, Madec G, Fischer AS, Lazar A, ludicone D (2004) Mixed layer depth over the global ocean : An examination of profile sata and a profile-based climatology. J. Geophys. Res., 109:C12003. doi: 10.1029/2004JC002378

Dee DP, Uppala SM, Simmons AJ, Berrisford P, Poli P, Kobayashi S, et al. (2011) The ERA-Interim reanalysis: configuration and performance of the data assimilation system. Q. J. R. Meteorol. Soc., 137:553-597. doi: $10.1002 /$ qj. 828

Delcroix T, Picaut J, Eldin G (1991) Equatorial Kelvin and Rossby waves evidenced in the Pacific Ocean through Geosat sea level and surface current anomalies. J. Geophys. Res.: Oceans, 96(S01):3249-3262. doi: 10.1029/90JC01758

Ding H, Keenlyside NS, Latif M (2010) Equatorial Atlantic interannual variability: Role of heat content. J. Geophys. Res., 115, C09020. doi: 10.1029/2010JC006304

Foltz GR, Grodsky SA, Carton JA, McPhaden MJ (2003) Seasonal mixed layer heat budget of the tropical Atlantic Ocean. J. Geophys. Res., 108(C5):3146. doi: 10.1029/2002jc001584

Foltz, GR, McPhaden MJ (2006) The role of oceanic heat advection in the evolution of tropical North and South Atlantic SST anomalies. J. Climate, 19(23):6122-6138. doi: 10.1175/JCLI3961.1

Giordani H, Caniaux G (2011) Diagnosing vertical motion in the Equatorial Atlantic. Ocean Dyn., 61(12):1995-2018. doi: 10.1007/s10236-011-0467-7

Giordani H, Caniaux G, Voldoire A (2013) Intraseasonal mixed-layer heat budget in the equatorial Atlantic during the cold tongue development in 2006. J. Geophys. Res.: Oceans, 118:650-671. doi: 10.1029/2012JC008280

Góes M, Wainer I (2003) Equatorial currents transport changes for extreme warm and cold events in the Atlantic Ocean. Geophys. Res. Lett., 30(5):8006. doi: 10.1029/2002GL015707

Good SA, Martin MJ, Rayner NA (2013) EN4: quality controlled ocean temperature and salinity profiles and monthly objective analyses with uncertainty estimates. J. Geophys. Res.: Oceans, 118:6704-6716. doi: 10.1002/2013JC009067

Gregg MC, Peters H, Wesson JC, Oakey NS, Shay TJ (1985) Intensive measurements of turbulence and shear in the equatorial undercurrent. Nature, 318:140-144. doi: 10.1038/318140a0 
Griffies SM, Winton M, Samuels B, Danabasoglu G, Yeager SG, Marsland S, Drange H, Brentsen M (2012) Datasets and protocol for the CLIVAR WGOMD Coordinated Ocean-sea ice Reference Experiments (COREs). WCRP Report No. 21/2012, pp. 21

Gu G, Adler RF (2004) Seasonal evolution and variability associated with the West African Monsoon system. J. Climate, 17:3364-3377. doi: 10.1175/1520-0442(2004)017<3364:SEAVAW >2.0.CO;2

Guinehut S, Dhomps AL, Larnicol G, Le Traon PY (2012) High resolution 3D temperature and salinity fields derived from in situ and satellite observations. Ocean Sci., 8(5):845-857. doi: 10.5194/os-8-845-2012

Hastenrath S, Lamb P (1978) On the dynamics and climatology of surface flow over the equatorial oceans. Tellus, 30:436-448. doi: 10.1111/j.2153-3490.1978.tb00859.x

Hieronymus M, Nycander J (2013) The budgets of heat and salinity in NEMO. Ocean Modelling, 67:28-38. doi: 10.1016/j.ocemod.2013.03.006

Hormann V, Brandt P (2007) Atlantic Equatorial Undercurrent and associated cold tongue variability. J. Geophys. Res.: Oceans. 112:C06017. doi: 10.1029/2006jc003931

Houghton RW (1989) Influence of local and remote wind forcing in the Gulf of Guinea. J. Geophys. Res.: Oceans, 94(C4):4816-4828. doi: 10.1029/JC094iC04p04816

Hummels R, Dengler M, Bourlès B (2013) Seasonal and regional variability of upper ocean diapycnal heat flux in the Atlantic Cold Tongue. Progress in Oceanography, 111:52-74. doi: 10.1016/j.pocean.2012.11.001

Hummels R, Dengler M, Brandt P, Schlundt M (2014) Diapycnal heat flux and mixed layer heat budget within in the Atlantic Cold Tongue. Clim. Dyn., 43(11):3179-3199. doi: 10.1007/s00382-014-2339-6

Jackett DR, McDougall TJ (1995) Minimal adjustment of hydrographic profiles to achieve static stability. J. Atmos. Oceanic Technol., 12(2):381-389. doi: 10.1175/1520-0426(1995)012<0381:MAOHPT>2.0.CO;2

Jochum M, Murtugudde R, Ferrari R, Malanotte-Rizzoli P (2005) The Impact of Horizontal Resolution on the Tropical Heat Budget in an Atlantic Ocean Model. J. Climate, 18(6)841-851. doi: 10.1175/JCLI-3288.1

Jochum M, Murtugudde R (2006) Temperature Advection by Tropical Instability Waves. J. Phys. Oceanogr., 36(4):592-605. doi: 10.1175/JPO2870.1

Jouanno J, Marin F, duPenhoat Y, Molines JM, Sheinbaum J (2011a) Seasonal Modes of Surface Cooling in the Gulf of Guinea. J. Phys. Oceanogr., 41(7):1408-1416. doi: 10.1175/JPO-D-11-031.1

Jouanno J, Marin F, duPenhoat Y, Sheinbaum J, Molines JM (2011b) Seasonal heat balance in the upper 100m of the Equatorial Atlantic Ocean. J. Geophys. Res., 116:C09003. doi: 10.1029/2010JC006912

Jouanno J, Marin F, duPenhoat Y, Molines JM (2013) Intraseasonal Modulation of the Surface Cooling in the Gulf of Guinea. J. Phys. Oceanogr., 43(2):382-401. doi: 10.1175/JPO-D-12-053.1

Kanamitsu M, Ebisuzaki W, Woolen J, Yang SK, Hnilo JJ, Fiorino M, Potter GL (2002) NCEP-DOE AMIP-II Reanalysis (R-2). Bull. Am. Meteorol. Soc., 83:1631-1643. doi: 10.1175/BAMS-83-11-1631

Keenlyside NS, Latif M (2007) Understanding equatorial Atlantic interannual variability. J. Climate, 20:131-142. doi: 10.1175/JCLI3992.1

Large WG, Yeager SG (2009) The global climatology of an interannually varying air-sea flux data set. Clim. Dyn., 33:341-364. doi: 10.1007/s00382-008-041-3

Lengaigne M, Menkes C, Aumont O, Gorgues T, Bopp L, André JM, Madec G (2007) Influence of the oceanic biology on the tropical Pacific climate in a coupled general circulation model. Clim. Dyn., 28(5):503-516. doi: 10.1007/s00382-006-0200-2

Lien RC, Caldwell DR, Moum JN (1995) Turbulence variability at the equator in the central Pacific at the beginning of the 1991-1993 El Niño. J. Geophys. Res.: Oceans, 100(C4):6881-6898. doi: 10.1029/94JC03312

Lien RC, D'Asaro EA, Menkes CE (2008) Modulation of equatorial turbulence by tropical instability waves. Geophys. Res. Lett., 35(24):L24607. doi: 10.1029/2008GL035860

Lübbecke JF, McPhaden MJ (2012) On the Inconsistent Relationship between Pacific and Atlantic Niños. J. Climate, 25(12):4294- 4303. doi: 10.1175/JCLI-D-11-00553.1

Lübbecke JF, Burls NJ, Reason CJ, McPhaden MJ (2014) Variability in the South Atlantic Anticyclone and the Atlantic Niño mode. J. Climate, 27:8135-8150. doi: 10.1175/JCLI-D-14-00202.1

Madec G. (2008) NEMO ocean engine. Note du Pole de modélisation, Institut Pierre-Simon Laplace (IPSL), France, No 27 ISSN No 1288-1619

Marin F, Caniaux G, Giordani H, Bourlès B, Gouriou Y, Key E (2009) Why Were Sea Surface Temperatures so Different in the Eastern Equatorial Atlantic in June 2005 and 2006? J. Phys. Oceanogr., 39(6):1416-1431. doi: 10.1175/ 2008JPO4030.1

Mazeika PA (1968) Mean monthly sea surface temperatures and zonal anomalies of the tropical Atlantic. folio 16. Am. Geographical Soc., New York

Merle J, Fieux M, Hisard P (1979) Annual signal and interannual anomalies of sea surface temperature in the eastern equatorial Atlantic Ocean. Deep-Sea Res., GATE Supplement II to V, 26:77-102

Morel A (1988) Optical modeling of the upper ocean in relation to its biogenous matter content (case-I waters). J. Geophys. Res.: Oceans, 93(C9):10749-10768. doi: 10.1029/JC09iC09p10749

Morel A, Maritorena S (2001) Bio-optical properties of oceanic waters: A reappraisal. J. Geophys. Res.: Oceans, 106(C4):7163-7180. doi: 10.1029/2000JC000319

Moum JN, Caldwell DR (1985) Local Influences on Shear-Flow Turbulence in the Equatorial Ocean. Science, 
230(4723) :315-316. doi : 10.1126/science.230.4723.315

Nguyen H, Thorncroft CD, Zhang C (2011) Guinean coastal rainfall of the West African Monsoon. Q. J. R. Meteorol. Soc., 137:1828-1840. doi: 10.1002/qj.867

Okumura Y, Xie SP (2004) Interaction of the Atlantic equatorial cold tongue and the African Monsoon. J. Climate, 17:3589-3602. doi: 10.1175/1520-0442(2004)017<3589:IOTAEC $>2.0$.CO;2

Perez RC, Lumpkin R, Johns WE, Foltz GR, Hormann V (2012) Interannual variations of Atlantic tropical instability waves. J. Geophys. Res., 117:C03011. doi: 10.1029/2011JC007584

Peter AC, Le Hénaff M, duPenhoat Y, Menkes CE, Marin F, Vialard J, Caniaux G, Lazar A (2006) A model study of the seasonal mixed layer heat budget in the equatorial Atlantic. J. Geophys. Res., 111:C06014. doi: 10.1029/2005JC003157

Philander SGH, Pacanowski RC (1981) Response of equatorial oceans to periodic forcing. J. Geophys. Res., 86(C3):1903-1916. doi: 10.1029/JC086iC03p01903

Picaut J (1983) Propagation of the seasonal upwelling in the eastern equatorial Atlantic. J. Phys. Oceanogr., 13:18-37. doi: 10.1175/1520-0485(1983)013<0018:POTSUI >2.0.CO;2

Picaut J, Masia F, duPenhoat Y (1997) An advective-reflective conceptual model for the oscillatory nature of the ENSO. Science, 277(5326):663-666. doi: 10.1126/science.277.5326.663

Praveen Kumar B, Vialard J, Lengaigne M, Murty VSN, McPhaden MJ (2012) TropFlux: air-sea fluxes for the global tropical oceans - description and evaluation. Clim. Dyn., 38:1521-1543. doi: 10.1007/s00382-011-1115-0

Redelsperger JL, Diedhiou A, Flamant C, Janicot S, Lafore JP, Lebel T, et al. (2006) Amma, une etude multidisciplinaire de la mousson oust-africaine. La Météorologie, 54:22-32. doi: 10.4267/2042/20098

Reynolds RW, Smith TM, Liu C, Chelton DB, Casey KS, Schlax MG (2007) Daily high resolution blended analysis for sea surface temperature. J. Climate, 20:5473-5496. doi: 10.1175/2007JCLI1824.1

Rhein M, Dengler M, Sueltenfuss J, Hummels R, Huttl-Kabus S, Bourlès B (2010) Upwelling and associated heat flux in the equatorial Atlantic inferred from helium isotope disequilibrium. J. Geophys. Res.: Oceans, 115:C08021. doi: 10.1029/2009JC005772

Richter I, Behera SK, Masumoto Y, Taguchi B, Sasaki H, Yamagata T (2013) Multiple causes of interannual sea surface temperature variability in the equatorial Atlantic ocean. Nature Geosci., 6(1):43-47. doi: 10.1038/ngeo1660

Richter I, Behera, SK, Doi T, Taguchi B, Masumoto Y, Xie SP (2014) What controls equatorial Atlantic winds in boreal spring? Clim. Dyn., 43(11):3091-3104. doi: 10.1007/s00382-014-2170-0

Saha S, Moorthi S, Thiaw C, Wang J, Nadiga S, Tripp P, et al. (2010) The ncep climate forecast system reanalysis. Bull. Am. Meteorol. Soc., 91:1015-3517. doi: 10.1175/2010BAMS3001.1

Schlundt M, Brandt P, Dengler M, Hummels R, Fischer T, Bumke K, Krahmann G, Karstensen J (2014) Mixed layer heat and salinity budgets during the onset of the 2011 Atlantic cold tongue. J. Geophys. Res.: Oceans, 119:78827910. doi: 10.1002/2014JC010021

Servain J, Picaut J, Merle J (1982) Evidence of remote forcing in the equatorial Atlantic Ocean. J. Phys. Oceanogr. 12:457-463. doi: 10.1175/1520-0485(1982)012<0457:EORFIT $>2.0$. CO;2

Suarez MJ, Schopf PS (1988) A delayed action oscillator for ENSO. Journal of the Atmospheric Sciences, 45(21):32833287. doi: 10.1175/1520-0469(1988)045<3283:ADAOFE $>2.0 . C O ; 2$

Taylor KE (2001) Summarizing multiple aspects of model performance in a single diagram. J. Geophys. Res., 107(D7):7183-7192. doi: 10.1029/2000JD900719

Voldoire A, Claudon M, Caniaux G, Giordani H, and Roehrig R (2014) Are atmospheric biases responsible for the tropical Atlantic SST biases in CNRM-CM5 coupled model? Clim. Dyn., 43(11):2963-2984. doi: 10.1007/s00382013-2036-x

Wade M, Caniaux G, duPenhoat Y, Dengler M, Giordani H, Hummels R (2011a) A one-dimensional modeling study of the diurnal cycle in the equatorial Atlantic at the PIRATA buoys during the EGEE-3 campaign. Ocean Dyn., 61(1):1-20. doi: 10.1007/s10236-010-0337-8

Wade M, Caniaux G, duPenhoat Y (2011b) Variability of the mixed layer heat budget in the eastern equatorial Atlantic during 2005-2007 as inferred using ARGO floats. J. Geophys. Res., 116:C08006. doi: 10.1029/2010JC006683

Waliser DE, Gautier C (1993) A satellite-derived climatology of the ITCZ. J. Climate, 6:2162-2174. doi: 10.1175/1520-0442(1993)006<2162:ASDCOT $>2.0$. CO;2

Wauthy B (1983) Introduction à la climatologie du Golfe de Guinée. Océanographie Tropicale, 18(2):103-138

Weingartner TJ, Weisberg RH (1991) On the annual cycle of equatorial upwelling in the Central Atlantic Ocean. J. Phys. Oceanogr. 21:68-82. doi: 10.1175/1520-0485(1991)021<0068:OTACOE $>2.0 . C O ; 2$

Woodruff SD, Worley SJ, Lubker SJ, Ji Z, Freeman JE, Berry DI, Brohan P, et al. (2011) ICOADS Release 2.5: Extensions and enhancements to the surface marine meteorological archive. Int. J. Climatol., 31(7):951-967. doi: $10.1002 /$ joc. 2103 